\title{
The Pannonian basin: Dynamic modelling of the transition from passive to active rifting
}

\author{
R. S. Huismans ${ }^{1 *}$, Y. Y. Podladchikov ${ }^{2}$, and S. A. P. L. Cloetingh ${ }^{3}$ \\ ${ }^{1}$ Institute of Earth Sciences, Vrije Universiteit, Amsterdam, The Netherlands \\ * present address: Geodynamics Group, Dep. Oceanography, Dalhousie University, Halifax, Canada \\ ${ }^{2}$ Geologisches Institut, ETH-Zentrum, Zürich, Switzerland \\ ${ }^{3}$ Institute of Earth Sciences, Vrije Universiteit, Amsterdam, The Netherlands
}

Received: 2 May 2000 - Accepted: 1 October 2001

\begin{abstract}
We examine a number of first order features of Pannonian basin evolution in terms of the feedback relation between passive far-field induced extension and active Raleigh-Taylor instable upwelling of the asthenosphere. We show that active mantle upwelling following a phase of passive extension are viable mechanisms explaining the Pannonian basin formation. The dynamic interplay between far-field driven passive extension and active thinning of the mantle lithosphere by convective upwelling beneath the rift zone is modelled using thermo-mechanical finite element methods. Our modelling results predict a first phase of passive lithospheric thinning which is followed by a second phase of late syn-rift to post-rift active mantle lithosphere thinning due to buoyancy induced flow beneath the rift zone. The pattern of coeval extension in the thinning region and compression in the flanking regions, predicted by the numerical model, may be explained by the buoyancy forces due to lithosphere thinning. It is demonstrated that time scales of and stresses generated by both processes are comparable. The model might also explain the occurrence of late shallow mantle related decompression melts in the Pannonian region and late regional doming.
\end{abstract}

\section{Introduction}

The Neogene Pannonian basin (Fig. 1) has since long been recognised as a key area for studying the evolution of rift basins. Its intermediate extension and the coeval occurrence of compression and subduction in the surrounding Carpathian and Dinaric chains characterise it as an intramontane rift basin. The availability of extensive high-quality data on crustal and lithospheric thickness, syn-rift and postrift fill, heat flow, stratigraphic control and it's sedimentary as well as structural evolution make it well suited for study

Correspondence to: R. S. Huismans

(ritske.huismans@dal.ca) of the dynamics of basin formation (Royden et al., 1982; Horvát, 1993).

The main features characterising the Pannonian basin pose a general problem in terms of extensional basin formation processes, e.g. the coeval occurrence of extension and compression, the strong differential thinning of the lithosphere beneath the Pannonian basin, its active post-rift evolution and the succession of calc-alkaline volcanics in the syn-rift stage by alkaline volcanics in the late syn-rift to post-rift stage. In terms of existing dynamic models the Pannonian basin is still enigmatic and until now no quantitative dynamic modelling attempt has been undertaken predicting the first order features characteristic of the region.

Passive rifting in a back-arc extensional setting, which has been proposed to explain the main features of the Pannonian basin (Royden et al., 1983b), may successfully explain only part of the observables, e.g. the crustal thinning pattern and the extensional features at the surface. The strong differential stretching, the late mantle-related volcanic activity and the coeval post-rift second phase of extension and postrift climax in compression in the East-Carpathians, however, cannot be explained by a simple passive rifting model alone (van Bemmelen, 1973; Stegena et al., 1975; Huismans et al., 2001b).

In order to explain these latter features several authors envisaged a mantle plume operating beneath the Pannonian basin (van Bemmelen, 1973; Stegena et al., 1975; Huismans et al., 2001b). However, since the mantle related features of the Pannonian basin system develop subsequent to the initiation of the passive rift, asthenospheric doming is a consequence of the previous rifting history and the role of a deep mantle plume must be ruled out.

Asthenospheric doming following the initiation of the rift zone is supported from a physical point of view since the lithosphere-asthenosphere boundary is basically unstable and, following a phase of lithospheric thinning, has the tendency to move upwards in a diapiric mode (Buck, 1985; Keen, 1985). This is due to the density inversion over the lithosphere-asthenosphere boundary, e.g. the shallow as- 


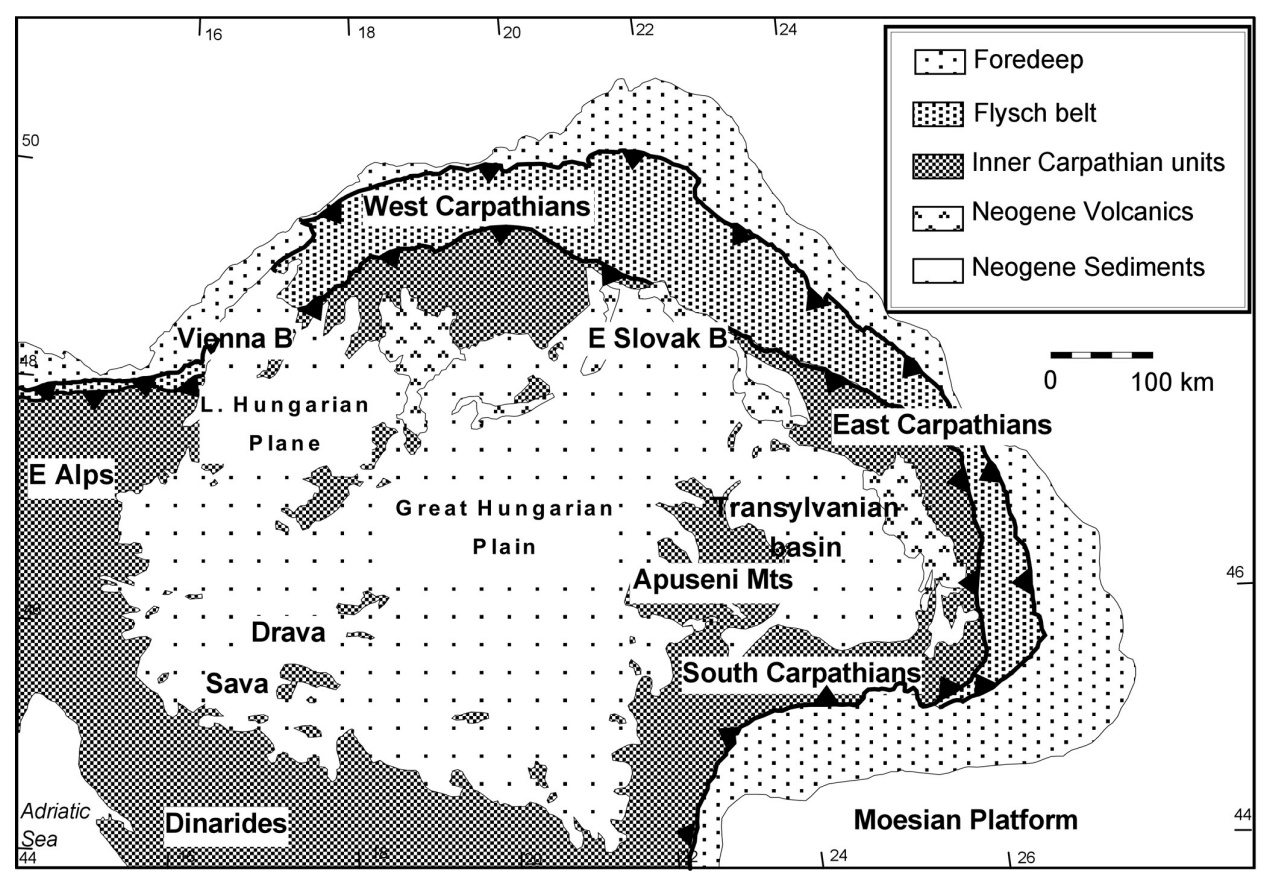

Fig. 1. Simplified overview of regional geology and geography of the Pannonian basin system (after Csontos, 1995).

thenosphere has a lower density then the mantle lithosphere. In the following, it will be shown that the first order features of the Pannonian basin can be explained by a first phase of passive extension followed by a second phase of active smallscale convective upwelling of the asthenosphere beneath the rift zone induced by the previous rifting history (Buck, 1985; Keen and Boutilier, 1995; Huismans et al., 2001a,b).

In the next sections we first describe in more detail the tectonic setting and the temporal evolution of the AlpineCarpathian-Pannonian system. Subsequently the numerical results are presented and compared with the general features of the region.

\section{The Pannonian basin: tectonic setting, regional geo- logic evolution and geological data}

Following a complex history of thickening and local basin formation from the late Early Cretaceous until the Early Miocene (100-19.5 Ma) extension in the Pannonian basin initiated on previously thickened crust and lithosphere (Stegena et al., 1975; Sclater et al., 1980; Royden et al., 1982; Csontos, 1995; Horvát, 1995). Strongest mantle lithosphere and crustal thinning have occurred in two NNE-SSW trending zones in the centre of the basin (Figs. 2a, b). At present, the Pannonian basin is characterised by anomalous high heat flow values (Sclater et al., 1980; Lenkey, 1999). The Neogene tectonic history of the Pannonian Carpathian system can be summarised in the following four main phases (Royden et al., 1983a; Horvát, 1993; Csontos, 1995).

1. Pre-rift thickening in the Late Oligocene to Early Miocene, with N-S to NW-SE compression.
2. The first rift phase, starting with opening of pull-apart basins at the borders of the Pannonian basin in an transtensional regime in the Karpathian (17.5-16.5 Ma) and pure extension in the Badenian (16.5-14 Ma).

3. A second phase which can be subdivided in:

(a) Slight inversion of the extending areas associated with a regional hiatus and possibly uplift and erosion coeval with the start of major compression in the East-Carpathians in the Late Sarmatian (13.511.5 Ma).

(b) A second rift phase in the Pannonian basin coeval with the climax of compression in the EastCarpathians in the Late Sarmatian and earliest Pannonian (11.5-8(?) Ma).

4. Post-rift subsidence, inversion and continued compression in the East-Carpathians and Eastern Alps until Recent.

\subsection{Structural evolution}

In order to be able to formulate the key question concerning the responsible tectonic processes, we summarise the structural evolution based on a compilation of work by different authors (Bergerat, 1989; Csontos et al., 1991; Ratschbacher et al., 1993; Horvát, 1993; Bergerat, 1995; Csontos, 1995; Fodor, 1995; Hippolyte and Sandulescu, 1996; Huismans et al., 1997; Matenco, 1997; Peresson and Decker, 1997a,b; Sanders, 1998; Fodor et al., 2000; Huismans and Bertotti, 2002). 

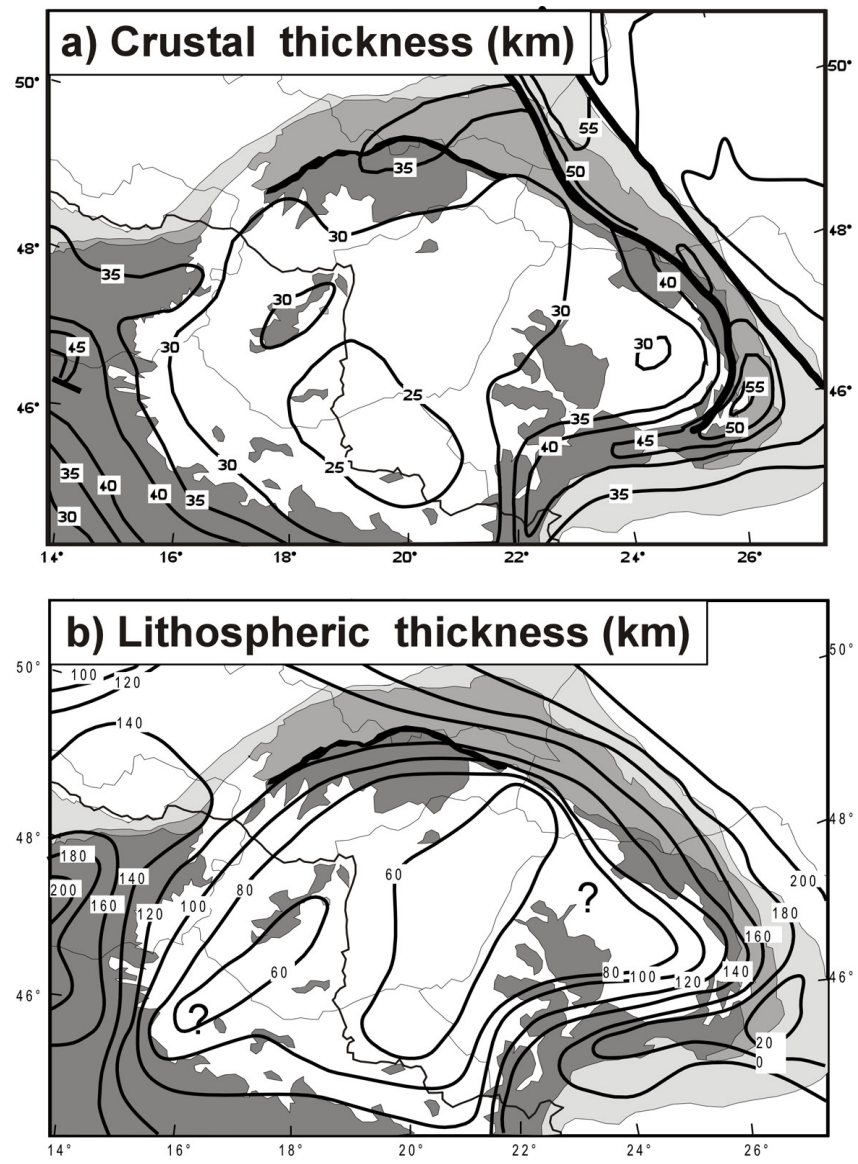

Fig. 2. Crust and mantle lithosphere thickness in the Pannonian region after Horvát (1993). Note the very high gradients in lithosphere thickness in the eastern and western part of the system.

Major block rotations are not considered in this reconstruction since the focus is on the Early Miocene to Recent evolution of the system and paleomagnetic data show that most of the rotations occurred prior to the early Middle Miocene initiation of the Pannonian basin, e.g. Csontos (1995) and references therein.

The central Parathetys subdivision of the Neogene deviates in its definitions from the standard stage and etage definitions due to faunal isolation of the Eastern Parathetys from the central Mediterranean realm. For convenience a time table is given in Fig. 3, correlating the Neogene timescale with the Eastern Parathetys time scale following Rögl (1996).

\subsection{Late Oligocene - Early Miocene pre-rift compression} (Fig. 4a)

The last major tectonic event before the onset of extension in the Pannonian basin is a widespread phase of (Fig. 4a) N$\mathrm{S}$ to NW-SE compression, documented by major compressional structures observed in the Eastern Alps (Peresson and Decker, 1997a), the Polish segment of the West-Carpathians (Birkenmayer, pers. communication), North-Transylvania (Huismans et al., 1997; Huismans and Bertotti, 2002), the
Time table of the Pannonian basin system

\begin{tabular}{|c|c|c|c|}
\hline$\stackrel{4}{\Sigma}$ & $\begin{array}{l}\text { I } \\
\text { Oั } \\
\text { ㅁ }\end{array}$ & AGE & $\begin{array}{l}\text { CENTRAL } \\
\text { PARATHETYS } \\
\text { STAGES }\end{array}$ \\
\hline \multirow[b]{3}{*}{5} & $\begin{array}{l}\text { Quater } \\
\text { nary }\end{array}$ & Calabrian & Pleistocene \\
\hline & \multirow{2}{*}{ 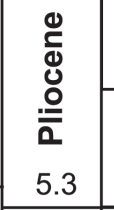 } & Piazenzian & Romanian \\
\hline & & Zanclean & $\begin{array}{l}\text { Dacian } \\
5.6\end{array}$ \\
\hline \multirow[b]{2}{*}{10} & \multirow{2}{*}{ 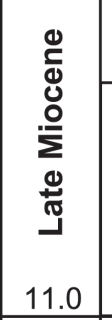 } & Messinian & Pontian \\
\hline & & $\begin{array}{c}7.1 \\
\text { Tortonian }\end{array}$ & $\begin{array}{c}\text { Pannonian } \\
11.5\end{array}$ \\
\hline \multirow{3}{*}{15} & \multirow{3}{*}{ 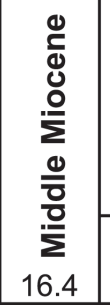 } & Serravalian & $\begin{array}{c}\text { Sarmatian } \\
13.0 \\
\end{array}$ \\
\hline & & 14.8 & \multirow{2}{*}{ Badenian } \\
\hline & & Langian & \\
\hline \multirow{4}{*}{20} & \multirow{4}{*}{ 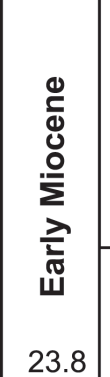 } & \multirow{3}{*}{ Burdigalian } & Karpathian \\
\hline & & & Ottnangian \\
\hline & & & $\begin{array}{c}18.3 \\
\text { Eggenburgian }\end{array}$ \\
\hline & & Aquitanian & Egerian \\
\hline
\end{tabular}

Fig. 3. Time table with central Parathetys stages after Rögl (1996).

Mid Hungarian retro-arc zone, e.g. Szolnok flysch (Csontos et al., 1992; Tari et al., 1993) and the Vienna Basin (Fodor, 1995).

At this stage the different micro-plates comprising the internal parts of the Pannonian area were assembled producing an initial thickening of the pre-rift lithosphere. At this time in the eastern part of the system, an embayment of thinned continental crust or oceanic crust was preserved north of the Moesian platform. Renewed initiation of westward subduction in the East-Carpathian arc accommodated eastward movement of the Pannonian pre-rift lithosphere leading to the first phase of extension. 

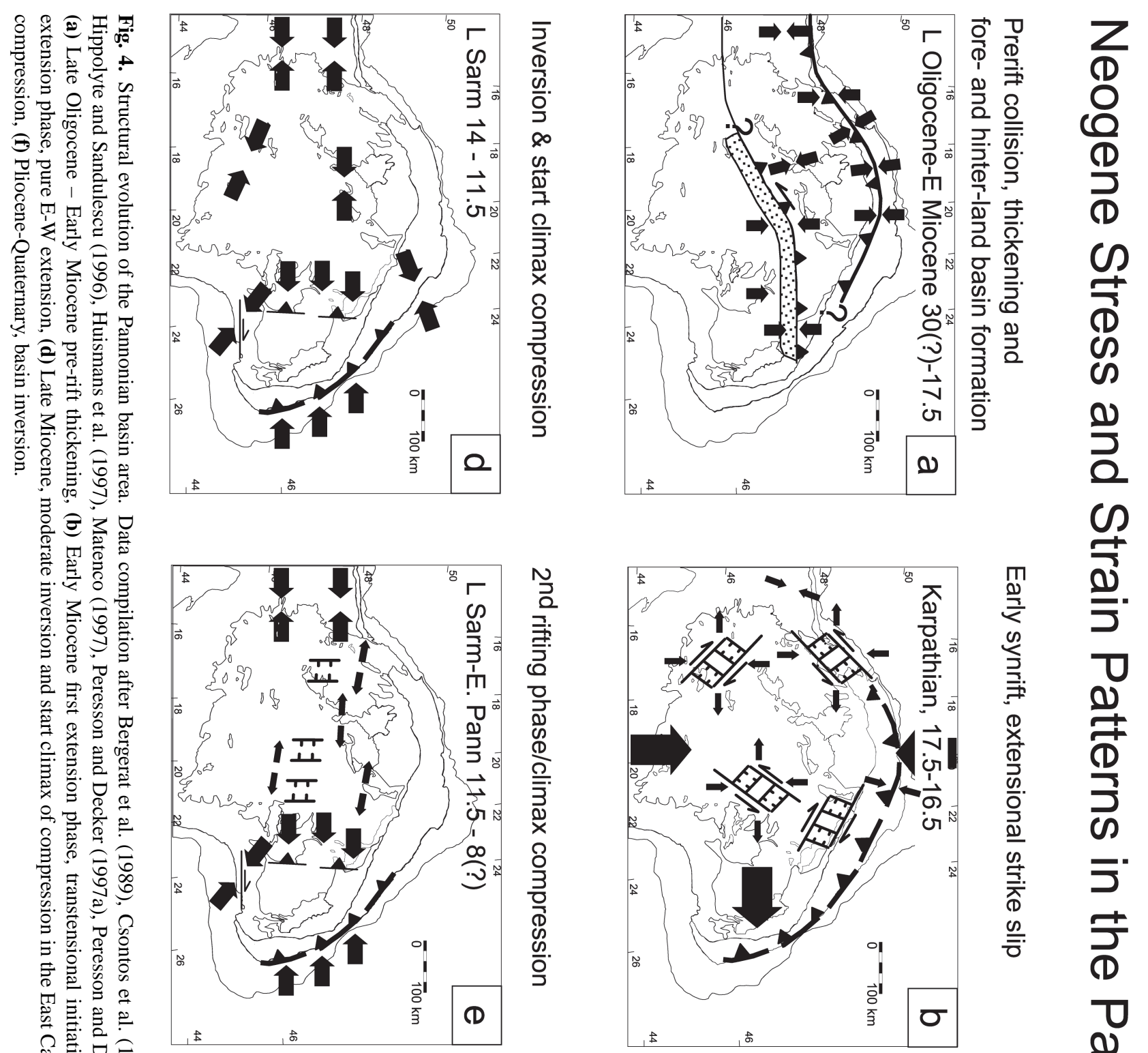

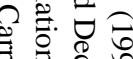

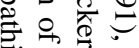

产总总

(2) 항 웡

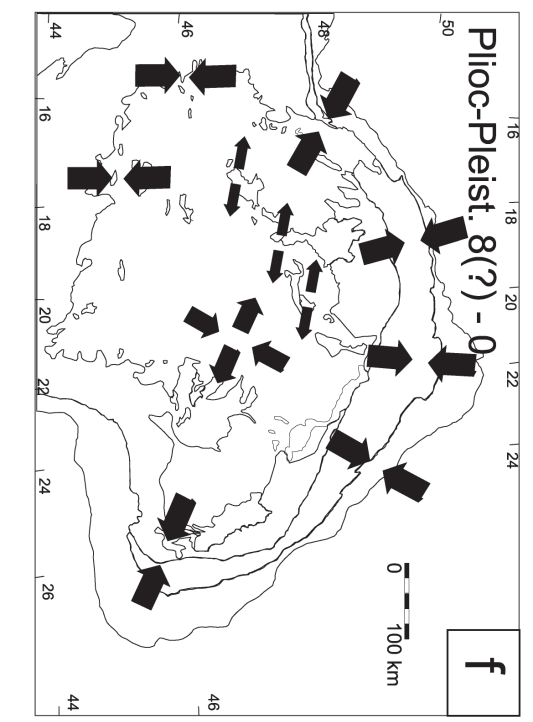

0
$\frac{0}{0}$
$\frac{0}{\mathbb{1}}$
$\frac{1}{2}$
$\frac{0}{2}$
$\overline{2}$
$\frac{1}{0}$
$\frac{1}{0}$
$\frac{0}{0}$
$\frac{1}{1}$

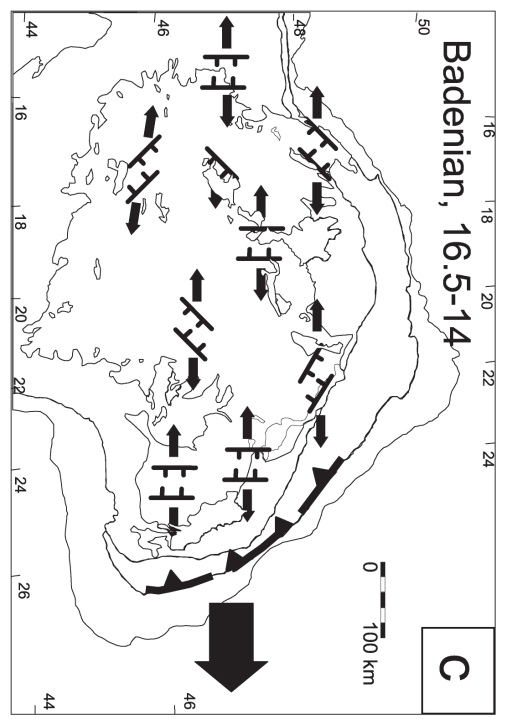




\subsection{Mid to Late Miocene 1th rift phase (Figs. 4b, c)}

The first phase of extension took place between 17.5-14 Ma (Horvát, 1995). Local very deep basins developed, associated with significant crustal thinning. On a regional scale, the crust and lithosphere where thinned in a more gradual way. Three basin areas separated by mountain areas may be distinguished (e.g. Fig. 1). (1) In the western part the Danube basin, (2) in the central part the Pannonian basin sensu stricto and (3) in the east the Transylvanian basin where only minor extension has taken place (Huismans et al., 1997; Huismans and Bertotti, 2002). Largest crustal thinning occurred beneath the central part of the Pannonian basin (Fig. 2a). A mid-Badenian (14 Ma) unconformity has been interpreted to mark the end of rifting (Horvát, 1995), while eastward escape and strike-slip continued in the Eastern Alps and the West-Carpathians (Royden et al., 1982; Ratschbacher et al., 1991; Lankreijer et al., 1995). The latter was accompanied with $\mathrm{N}-\mathrm{S}$ extension attributed to widening of Eastern Alpine blocks which were expulsed towards the east (Neubauer et al., 2000).

In the Karpathian (17.5-16.5 Ma), basin formation is characterised by an overall extensive strike-slip regime with dextral and sinistral pull-apart basins opening predominantly at the rims of the future Pannonian basin area, e.g. the Styrian basin in the west, the Vienna Basin in the north-west, the East Slovak Basin in the north-east, the Drava and Sava troughs in the south-west and the Bekes and Mako troughs in the east. Subsequently, in the Badenian (16.5-14), pure E$\mathrm{W}$ extension thinned the central parts of the basin (Bergerat, 1989; Csontos, 1995) with possible core complex style extension in the western part of the Pannonian basin area (Tari and Bally, 1990).

Although basins where locally affected by either NE-SW or NW-SE extension. On a larger scale, the local subbasins accommodated an overall E-W extension that affected the whole region between the Eastern Alps and the Eastern Carpathians (Bergerat, 1989; Peresson and Decker, 1997b; Huismans and Bertotti, 2002).

The eastern part of the system, e.g. the Transylvanian basin and the internal parts of the East and South-Carpathians, experienced relative quiet tectonic conditions during this time with minor extension taking place in the Middle to Late Miocene (Huismans et al., 1997; Huismans and Bertotti, 2002).

\subsection{Late Sarmatian inversion (Fig. 4d)}

At the end of the Sarmatian, the Pannonian basin was affected by a compressional event, as is suggested by seismic data (Horvát, 1995). Uplift and intensive erosion is documented by the fact that the Sarmatian is missing in many parts of the Pannonian basin. In the Early Pannonian subsidence and sedimentation were again re-established. The stress field for the inversion is characterised by ENE-WSW to E-W compression (Fodor et al., 2000). In the central Pannonian area, NE-SW trending faults were reactivated as dextral strike-slip faults. Peresson and Decker (1997) documented E-W $\sigma_{1}$ directions in the Eastern Alps for the Early Pannonian (Peresson and Decker, 1997a). Part of this compressional activity, however, may already have started in the Late Sarmatian and be associated with the inversion recorded in the Pannonian basin.

2.5 IV. Late Sarmatian - earliest Pannonian: second rift phase coeval with climax of compression in the EastCarpathians (Fig. 4e)

E-W extensional structures found in the central and western parts of the Pannonian basin (Fodor et al., 2000) and accelerated subsidence and sedimentation rate of the main subbasins of the area (Lankreijer et al., 1995) document a second phase of extension for the Late Miocene to Early Pliocene (11.5-8(?) Ma). Coeval with this second extensional phase, a strong compressional pulse affected the region to the east and to the west of the Pannonian basin (Huismans et al., 1997; Peresson and Decker, 1997a; Sanders et al., 1999; Huismans and Bertotti, 2002).

Compressional deformation reached its climax in the EastCarpathians around 11.5-8(?) Ma. Apatite fission track analysis documents fast cooling and exhumation for this time interval (Sanders et al., 1999). Not only the East-Carpathians but the transition zone until the Pannonian basin, e.g. the Transylvanian basin and the Apuseni Mts. experienced strong E-W compressional deformation (Huismans et al., 1997; Huismans and Bertotti, 2002). To the west of the Pannonian basin the Eastern Alps and the Vienna basin were as well affected by a pulse in E-W compression (Peresson and Decker, 1997a; Fodor et al., 2000).

2.6 V. Pannonian to Recent: Inversion, continued compression in the Eastern Carpathians to Eastern Alps and present day stress field (Fig. 4f)

During the Late Miocene to Recent, the Pannonian basin became locked and the region suffered from a compressional stress field with varying stress orientations (Horvát and Cloetingh, 1996). The stress field in the mountain areas at the rims of the Pannonian area is predominantly of compressive and compressive strike-slip type, with the largest compressive stress in general normal to the strike of the orogen. This results in a radial stress pattern.

Clear inversion has taken place on the southern border of the Pannonian basin with the Dinarides (Horvát, 1995). In the Eastern and South-Carpathians, active deformation shifted toward to bend zone with at present N-S compression in the Vrancea area (Hippolyte and Sandulescu, 1996). Stress indicators for the East and South-Carpathians and the Transylvanian basin show that an E-W to NW-SE compressive stress field prevails. In the Central and Western Pannonian basin, transtension to E-W extension has been documented in basalts as young as $2 \mathrm{Ma}$. 


\section{Subsidence basins at borders}

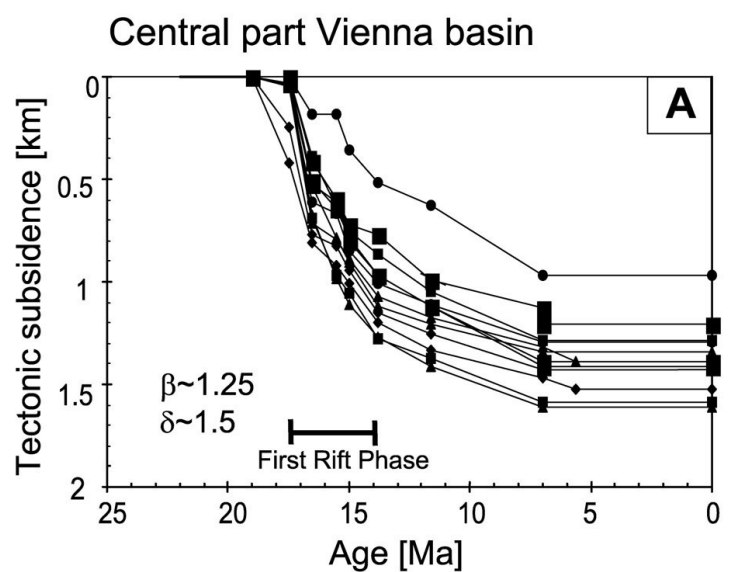

East Slowak basin

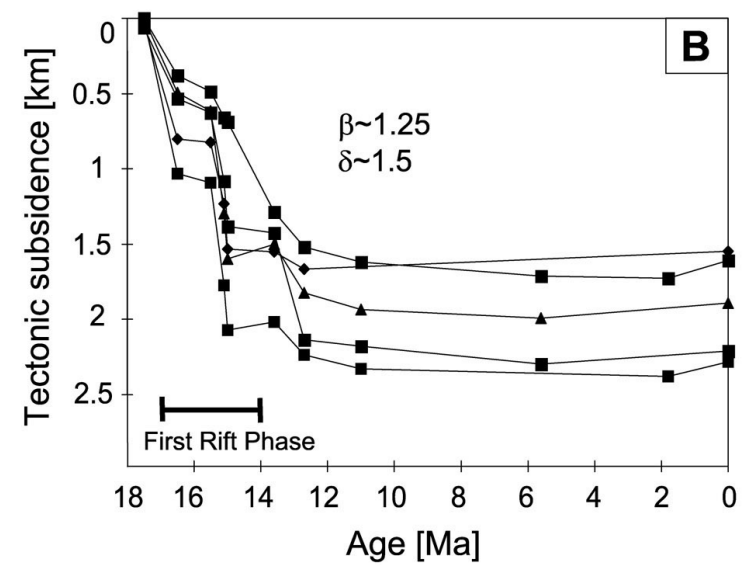

\section{Subsidence basins in Centre}

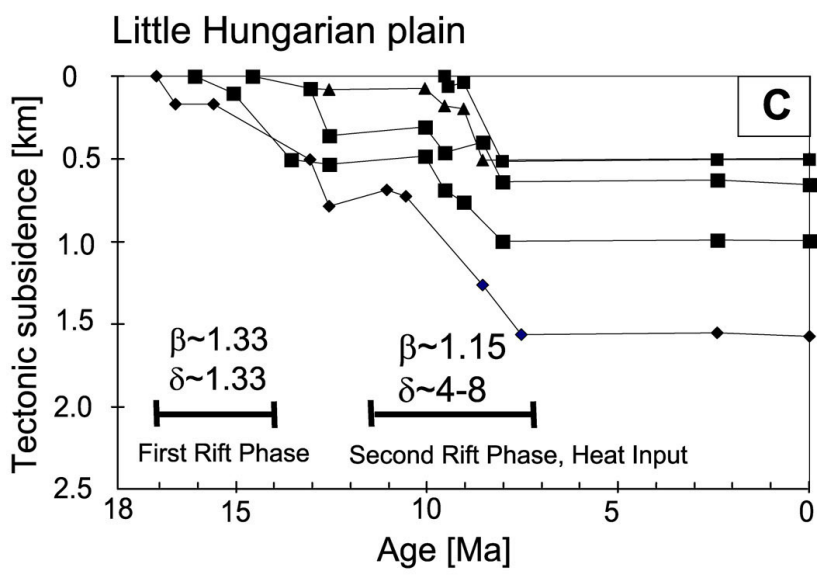

Great Hungarian plain

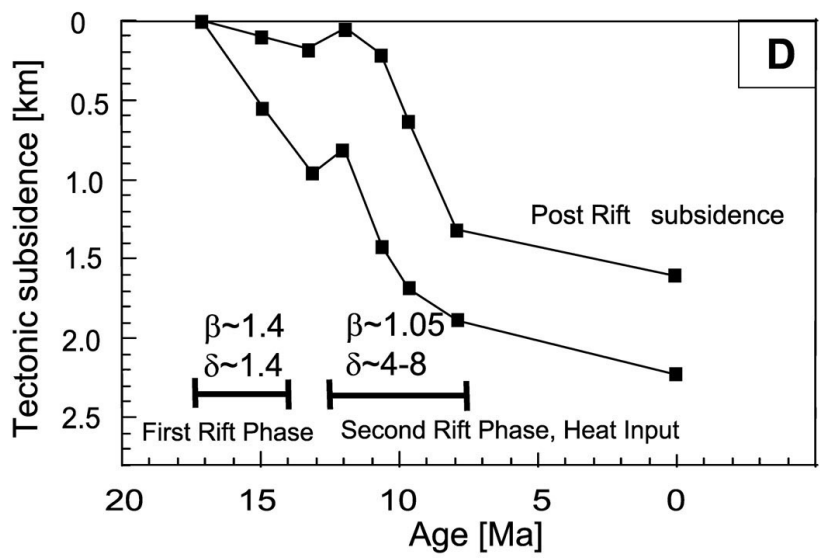

Fig. 5. Contrasting tectonic subsidence at the borders of the Pannonian basin and in the central basin areas, data after Royden (1982) and Lankreijer et al. (1995). (a) the Vienna basin, (b) the the East Slowak basin, (c) the little Hungarian plane, (d) the Great Hungarian plane. Note first rift phase 17.5-14 Ma, homogeneous thinning, Second rift phase 12-8 Ma, strong differential thinning.

\subsection{Constraints from basin analysis}

Several studies document the Neogene subsidence and sedimentation history of the main sub basins of the Pannonian basin system (Sclater et al., 1980; Royden et al., 1983b; Lankreijer et al., 1995; Sachsenhofer et al., 1997). It appears that the central Pannonian basin is characterised by two extensional stages (Lankreijer et al., 1995; Fodor et al., 2000). Typical subsidence histories for the border and central areas are illustrated in Fig.s 5a-d (Royden et al., 1983b; Lankreijer et al., 1995).

Whereas the first Karpathian to Badenian (17.5-14 Ma) rift phase affected the basins located at the borders of the Pannonian basin as well as the central Pannonian basin, the second Early Pannonian (11.5-8(?) Ma) rift phase is only evident in the central parts of the Pannonian basin. During the first rift phase crust and lithosphere where thinned by equal amounts with $\beta$ and $\delta$ factors in the order 1.4-1.6 (Royden et al., 1983b; Lankreijer et al., 1995)(e.g. Figs. 5a and 5b).

After a period of non deposition and/or erosion, coeval with a phase of inversion in the Late Sarmatian - Early
Pannonian the second rift phase affected predominantly the central parts of the Pannonian basin in the Early Pannonian. In this phase strong differential thinning of the mantle lithosphere in the order of $\delta=4-8$, is required to explain the observations (Sclater et al., 1980; Royden et al., 1983b; Lankreijer et al., 1995), whereas only minor additional thinning affected the crust. Subsidence analysis for the Little Hungarian Plain and for the Great Hungarian Plain illustrates the two-stage extensional history of the Pannonian basin (Figs. 5c and 5d) (Royden et al., 1983b; Lankreijer et al., 1995).

The strong spatial correlation between areas affected by the second rift phase and extreme lithospheric thinning, clearly indicate a causal relation between asthenospheric updoming and the second rift phase.

\subsection{Volcanism}

The Neogene development of the Pannonian basin was accompanied by strong volcanic activity (Szabo et al., 1992; Balogh et al., 1994; Downes and Vaselli, 1995; Embey-Isztin 


\section{a) Age ranges of the Calc Alkaline volcanics}

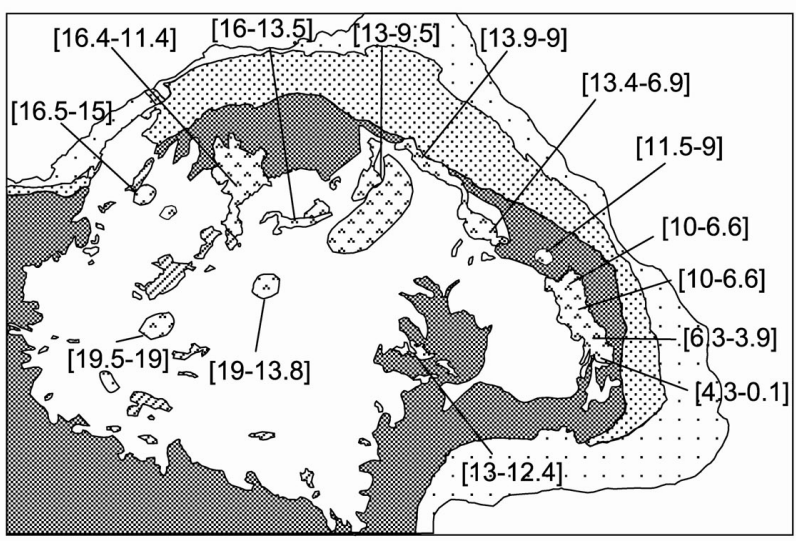

b) Age ranges of the Alkaline volcanics

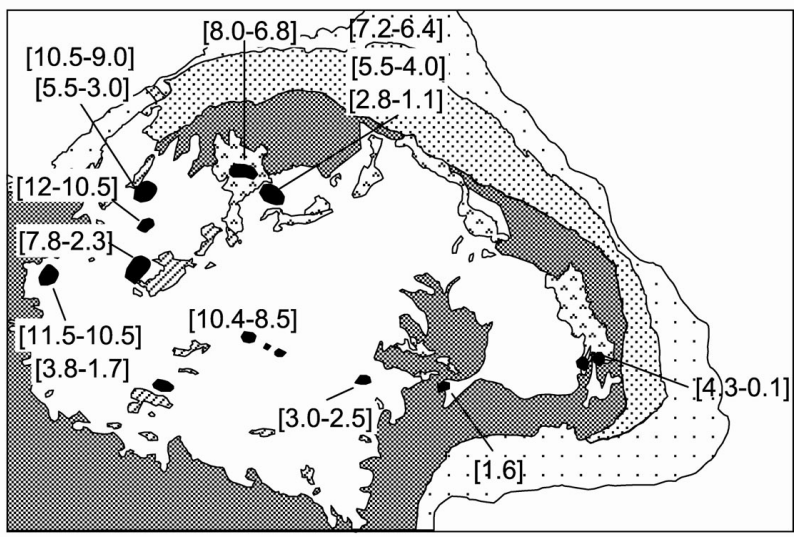

Fig. 6. Age ranges of volcanic activity in the Pannonian basin system, data compiled from Szabo (1992), Balogh et al. (1994), Downes and Vaselli (1995), Pecskay et al. (1995). (a) Calc-Alkaline volcanics. Note younging along the Carphathian arc towards the east. (b)Alkaline volcanics. Note younger ages then the calc-alkaline volcanics and two peaks in alkaline volcanic activity (10 Ma and 2-0 Ma).

and Dobosi, 1995; Pecskay et al., 1995; Vaselli et al., 1995). The timing and character of the volcanism observed in the Pannonian basin provide important constraints on the large scale processes responsible for the basin formation history. Three volcanic suites can be distinguished:

1. Early Miocene mainly acidic calc-alkaline ignimbrites and tuff deposits extend over most of the Pannonian basin, the Transylvanian basin and their margins.

2. Middle Miocene to Recent, probably subductionrelated, calc-alkaline volcanics occur in the inner WestCarpathians and in a linear belt parallel to the EastCarpathian thrust belt (Fig. 6a).

3. Late Miocene to Recent alkaline basaltic shallow mantle related decompression melts occurring in a more diffuse pattern over the Pannonian region (Fig. 6b).

The last two suites partly overlap in time (Szabo et al., 1992; Downes and Vaselli, 1995; Pecskay et al., 1995).

The occurrence of calc-alkaline volcanism is diachronous with younger ages going from the West-Carpathians towards the southern tip of the East Carpathians. In the West-Carpathians calc-alkaline volcanism starts in the Middle Karpathian slightly after the beginning of rifting in the Pannonian basin and lasted until the late Sarmatian-Early Pannonian, 17-9.6 Ma, whereas in the internal parts of the East Carpathians ages range from Middle Badenian to Recent, 15-0.07 Ma (Fig. 6a; for a compilation on ages and chemistry see Szabo, 1993). This volcanic suite is generally interpreted to be related to underthrusting and subduction of the East-European foreland crust beneath the Pannonian basin.

The first occurrence of alkaline basalts is around 11.5 Ma, coeval with the second rift phase and with strong mantle lithosphere upwelling (Fig. 6b). Most important occurrences are in the Balaton highlands and the in the Graz basin, slightly west of the centre of maximum thinning in the Pannonian basin (Downes and Vaselli, 1995). Ages range from 11.5-0.5 Ma, with a peak in the Pannonian around 7-8 Ma (Szabo et al., 1992; Balogh et al., 1994; Pecskay et al., 1995).

Geochemical analysis of the alkaline volcanics point to a shallow asthenospheric source (Downes and Vaselli, 1995; Embey-Isztin and Dobosi, 1995; Dobosi et al., 1995). The small volumes of the basaltic lavas and low eruption rates indicate that the potential temperature of the asthenosphere was probably not higher then normal.

\section{Previous models and outstanding questions for the formation of the Pannonian basin system}

We focus on two closely interrelated questions pertaining to the Pannonian basin system evolution. (1) What is the responsible process for strong mantle lithosphere thinning during the second rift phase? (2) What is the driving force for the coeval second phase of rifting in the Pannonian basin and the climax of compression in the East-Carpathians?

Earlier models proposed to explain part or all of the Pannonian basin system evolution fall into three distinct classes.

1. Eastern Alps collapse and escape models, where the Eastern Alpine crust is thought to have moved for more then $200 \mathrm{~km}$ in the open oceanic (?) embayment of the Pannonian region (Ratschbacher et al., 1991).

2. Back-arc extension models relating the extensional history of the Pannonian basin to subduction and a retreating slab beneath the East- Carpathian arc (Sclater et al., 1980; Royden et al., 1983b; Horvát, 1993).

3. Models related to active mantle upwelling beneath the Pannonian basin (van Bemmelen, 1973; Stegena et al., 1975; Huismans et al., 2001a). 


\section{a) Stresses due to subduction}

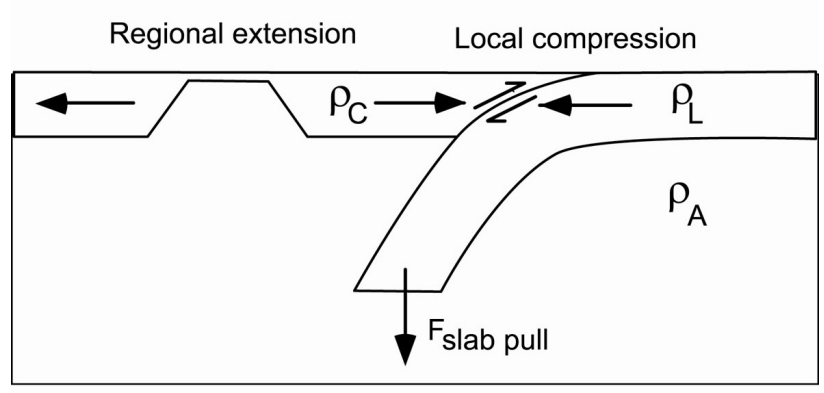

b) Stresses due to rift push

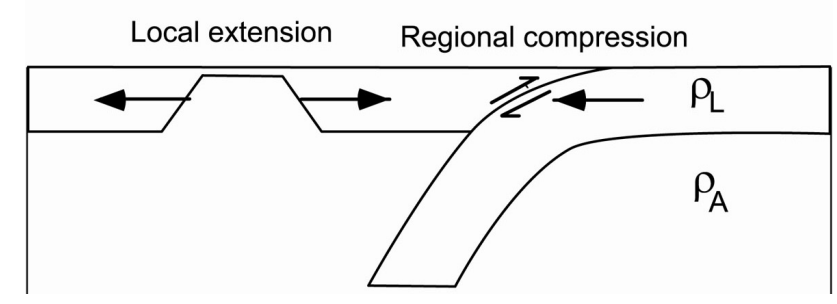

Fig. 7. Characteristic stress patterns for arc-back-arc systems with coeval occurring extension and compression. (a) System dominated by slab roll-back and related back-arc extension. Typical pattern of local compression due to accretionary wedge tectonics and regional extension due to slab roll back. (b) System dominated by rift push forces in the back-arc region. Typical pattern one of local extension in the back-arc zone and regional compression around the rift zone generated by rift push forces.

Each of these models separately has its intrinsic merits and problems when applied to the Pannonian basin system. Below, a simple area balancing of the amount of extension in the Pannonian basin with the amount of contraction in the EastCarpathians shows that extrusion tectonics is probably of minor importance for the basin formation history of the Pannonian basin. The two remaining candidates, subduction and related back-arc extension and asthenospheric doming each may explain only part of the tectonic history. A model based only on the effects of asthenosphere doming has difficulty explaining the initiation of the first rift phase, with overall extension behind the Carpathian arc. Attempts to explain the Pannonian basin only in terms of subduction-related back-arc extension have trouble explaining the strong observed differential thinning of the mantle lithosphere associated with the second rift phase and the coeval occurrence of extension and compression.

3.1 Coeval extension and compression in the Pannonian basin

The coeval occurrence of extension and compression in regions not very far apart can be either explained by subduction and back-arc extension (see for instance Royden, 1993) or by the role of the rift push forces. The relative role of these two processes can be addressed by considering the typical force/stress distributions for the different conceptual models. The tectonic history of the Transylvanian basin and the Apuseni Mts. area, which form the transition region between the extending region in the Pannonian basin and the collisional zone in the East-Carpathian arc, is critical in constraining the relation between these two areas.

The three main classes of models proposed to explain the opening of back arc basins are mantle diapirism (Karig, 1971), induced asthenosphere convection (Toksöz and Hsui, 1983), and global plate kinematics(Chase, 1978). The third class of models appears to provide the most consistent predictions when compared to the spatial and temporal evolution of back arc basins (Taylor and Karner, 1983). This type of model predicts that a back arc basin should form whenever global plate interactions require divergence between the overriding plate and the trench line. Analog model experiments, which fall in this class of models (Shemenda, 1989, 1993) predict that the pattern of stress in the tectonic environment of back-arc extension is characterised by overall extension in the overlying plate and local compression near the contact zone between the down going plate and the overlying plate (Fig. 7) (Shemenda, 1993). In the case of a situation dominated by rift push forces, local extensional stresses affect the rift zone, whereas the region surrounding the rift zone is affected by overall compressional stresses (Fig. 7b (Bird, 1978; Turcotte and Emerman, 1983; Le Pichon and Alvarez, 1984).

It appears that the two-stage rift evolution, which characterises the Pannonian basin system, can be explained by these two end member processes responsible for coeval extension and compression. The first rift phase can be explained with a passive rift event driven by far-field extensional forces resulting from slab roll-back and related back-arc extension. The second rift phase, associated with strong asthenosphere upwelling and alkaline volcanism is interpreted here in terms of the buoyancy forces associated with lithosphere thinning.

In the following we will first give estimates of the amount of Eastern Alps extrusion to the east. Then dynamic modelling of the two-stage extensional history of the Pannonian basin will be presented. In the end the results will be summarised and the merits of back-arc extension models and asthenosphere diapir models for the tectonics of the Pannonian basin system will be discussed in view of the presented results.

\subsection{Estimating Eastern Alps Escape}

It has been argued that the amount of shortening in the East-Carpathians balances roughly with estimates of overall crustal extension for the Pannonian basin (Royden et al., 1983b). A simple area balancing of convergence in the Eastern Carpathian arc with extension in the Pannonian basin area gives an estimate of the amount of space available for extrusion of the Eastern Alps to the east. Restoring the EastCarpathian thrust belt to the Early Miocene pre-rift configurations gives an estimate of 150-200 km eastward translation of the thrust belt (Fig. 8a) (Ellouz and Roca, 1994). 


\section{a) Paleogeographic reconstructions of the E-Carpathian thrust front}
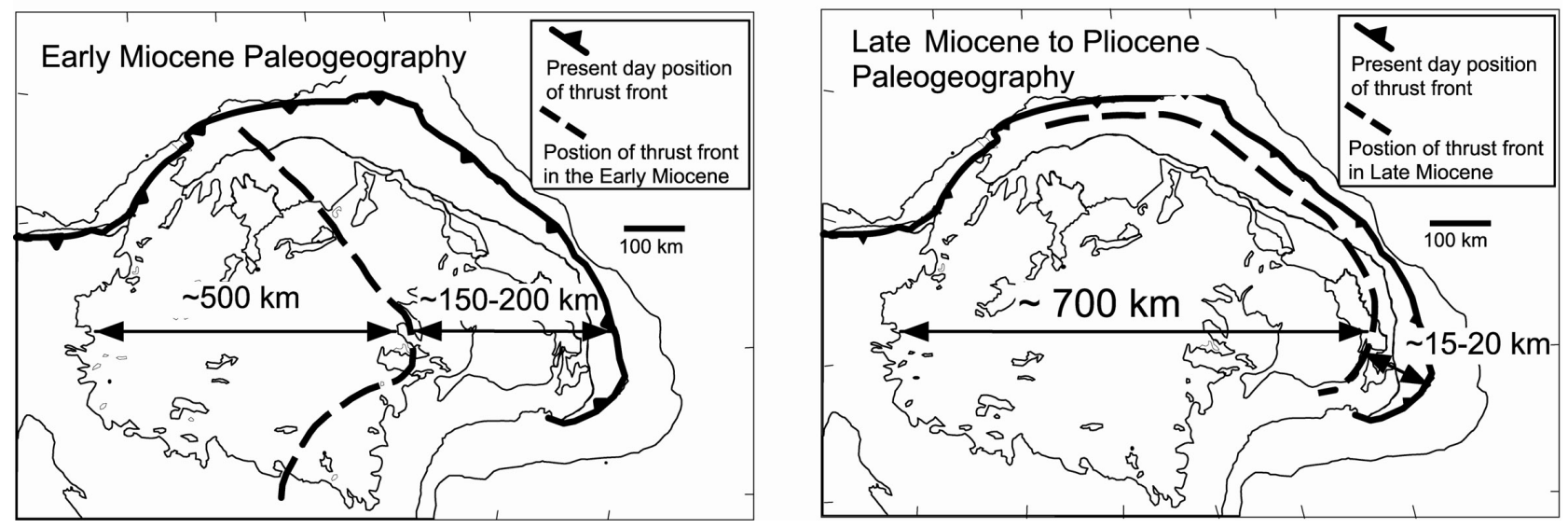

Fig. 8a. Estimates of Eastern Alps escape. (a) Paleogeographic reconstruction of the position of the East-Carpathian thrust front in the Neogene (after Ellouz and Roca, 1994). (b) Balancing extension and compression in the Pannonian basin system. An estimate of the amount of Eastern Alps escape is obtained by balancing eastward translation of the East-Carpathians with average extension in the Pannonian basin.

\section{b) Balancing extension and compression}

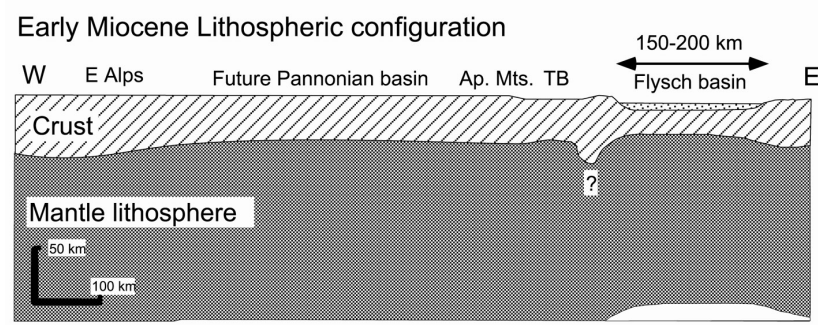

Present day Lithospheric configuration
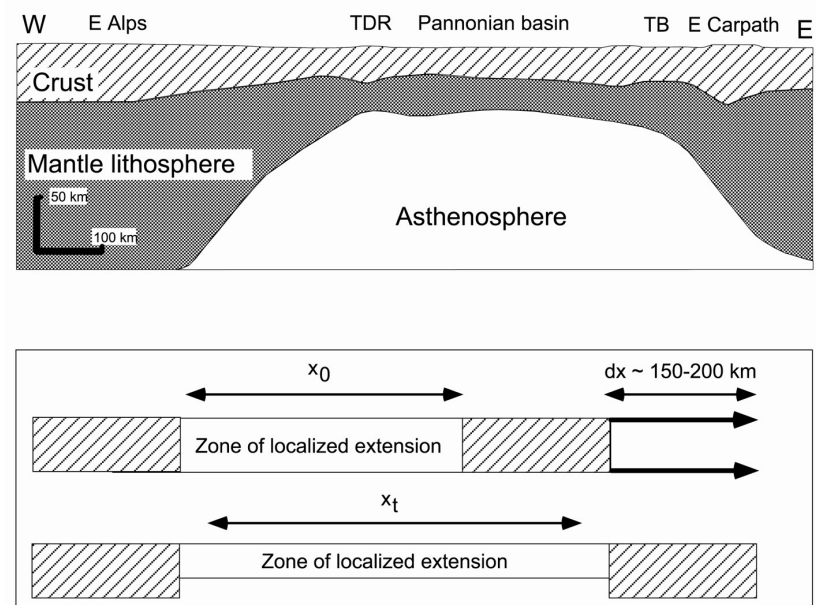

Fig. 8b. ... continued.

We consider a section reaching from the East-Carpathians in the east to the Eastern Alps in the west (Fig. 8b). It is assumed that extension and compression take place in a two dimensional plane. This is justified by the fact that although on a local scale extension directions varied considerably, overall extension and contraction occurred in an E-W direction, e.g. see above and Bergerat (1989). Since the crustal thinning factor $\beta$ is defined as the ratio of initial crustal thickness divided by the final crustal thickness, it is equivalent to define the crustal stretching factor $\beta$ as the final length $X_{t}$ of the region undergoing extension divided by the initial length $X_{0}$. Thus an estimate of the initial length is given by:

$X_{0}=\frac{X_{t}}{\beta}$

The mean value of crustal thinning is in the order of $\beta=$ 1.6-1.8 (Royden et al., 1983b; Lankreijer et al., 1995). The final length of the thinned region is in the range $350-550 \mathrm{~km}$. If a final length of $X_{t}=350 \mathrm{~km}$ is taken, the initial length $X_{0}$ is in the range $190-220 \mathrm{~km}$, whereas $X_{t}=550 \mathrm{~km}$ results in $X_{0}=310-350 \mathrm{~km}$. In this approximation the amount of possible eastward movement of the Eastern Alps, $X_{\text {escape }}$, is given by the amount of translation of the Eastern Carpathians, $D_{x}$, minus the length change of the Pannonian region:

$X_{\text {escape }}=D_{x}-\left(X_{t}-X_{0}\right)$.

The amount of escape obtained in this way is in the range $0-50 \mathrm{~km}$. This is much less then the stated $200 \mathrm{~km}$ of Eastern Alps escape to the east (Ratschbacher et al., 1991). Although, obviously, three dimensional effects may be important, overall extension and compression occurred in an E-W direction and the above gives a reasonable first order estimate of the amount of eastward movement of the Eastern Alps at the time of rifting in the Pannonian basin. Large lateral eastward motion has been proposed for the North Pannonian unit. Structural data for the Eastern Alps indicate that eastward movement started in the Oligocene. This together with the aruments given above suggests that Eastern Alps escape is probably of minor importance for the Neogene extensional history of the Pannonian basin system. 


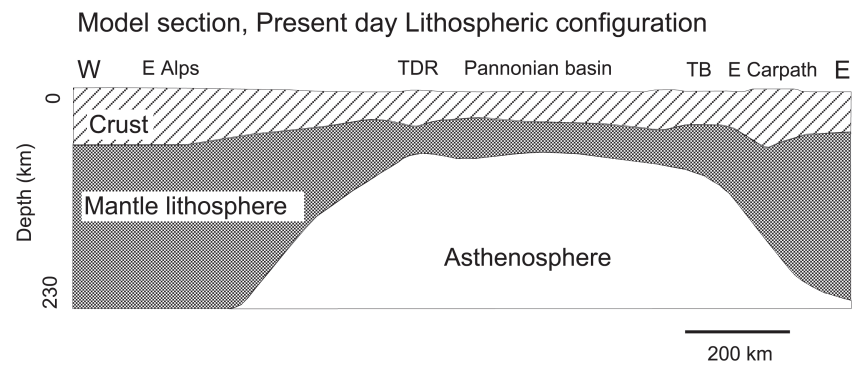

Fig. 9. Present-day crust and lithosphere configuration along an EW section through the Pannonian basin system (after Horvát, 1993).

\section{Finite element modelling of small-scale convective up- welling following passive rifting}

A 2-D thermo-mechanical finite element model is applied to the Pannonian basin history to investigate the conditions of small-scale convective upwelling following the first passive rift phase. We consider an E-W section reaching from the Eastern Alps to the East-Carpathians (Fig. 9). Although the Pannonian basin exhibits notable 3-dimensional features, overall extension and translation of the East-Carpathians occurred in an E-W direction. The fact that asthenospheric upwelling exhibits a N-S to NNE-SSW axis of symmetry (Fig. 2) further supports the notion of overall E-W extension. It appears therefore, in a first approximation, reasonably justified to model the Pannonian basin history in a 2dimensional east-west section.

The equations of static equilibrium are solved in a 2dimensional plain strain mechanical model. A fully dynamic, pressure and temperature dependent visco-elasto-plastic rheology is used. Changes in the temperature field due to advection and conduction are calculated during run time. The temperature dependence of density is included.

Mechanical boundary conditions include horizontal velocities applied at the sides of the model with free slip in the vertical direction. The lower part of the model has been fixed in the vertical direction with free slip in the horizontal direction. The upper surface is free to move in the vertical direction. Thermal boundary conditions include fixed temperatures at the surface and the lithosphere-asthenosphere boundary and zero lateral heat flux through the side boundaries. A more detailed description of the model is given in Huismans (2001a).

The model is composed of three layers which represent the upper crust, the lower crust and the mantle. The nonlinear temperature dependent viscous behaviour of the model is determined by power law creep parameters of dry granite (upper crust), diabase rheology (lower crust) and dry olivine (mantle) (Carter and Tsenn, 1987). Brittle behaviour is modelled by a Mohr-Coulomb plastic flow criterion with parameters consistent with Byerlee's law (for the parameters used see Table 1). For the initial geometry and the mesh used see Fig. 10.

\section{Geometry and boundary conditions}

Finite element mesh thick crust model

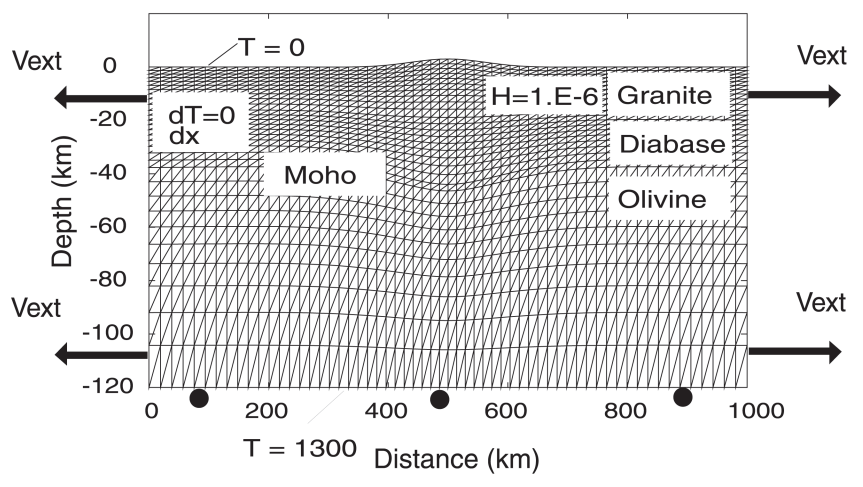

Fig. 10. Finite element model setup. Mesh and boundary conditions.

Table 1. Model Parameters

\begin{tabular}{|c|c|c|}
\hline Symbol & Meaning & Value \\
\hline$E$ & Youngs modulus & $10^{10} \mathrm{~Pa}$ \\
\hline$G$ & shear modulus & $10^{10} \mathrm{~Pa}$ \\
\hline$v$ & Poisson's ratio & 0.25 \\
\hline$\phi$ & angle of friction & $30^{\circ}$ \\
\hline$\psi$ & angle of dilatation & $0^{\circ}$ \\
\hline$S_{0}$ & cohesion & $2 \times 10^{7} \mathrm{~Pa}$ \\
\hline$\rho_{u c 0}$ & density $\mathrm{u}$-crust $0^{\circ} \mathrm{C}$ & $2700 \mathrm{~kg} \mathrm{~m}^{-3}$ \\
\hline$\rho_{l c 0}$ & density 1 -crust $0^{\circ} \mathrm{C}$ & $2800 \mathrm{~kg} \mathrm{~m}^{-3}$ \\
\hline$\rho_{m 0}$ & density mantle $0^{\circ} \mathrm{C}$ & $3300 \mathrm{~kg} \mathrm{~m}^{-3}$ \\
\hline$\alpha$ & thermal expansion & $3.1 \times 10^{-5 \circ} \mathrm{C}^{-1}$ \\
\hline$k$ & thermal conductivity & $2.6 \mathrm{~W} \mathrm{~m}^{-1 \circ} \mathrm{C}^{-1}$ \\
\hline$c_{p}$ & specific heat & $1050 \mathrm{~m}^{-2} \mathrm{~s}^{-2 \circ} \mathrm{C}^{-1}$ \\
\hline$H$ & heat production & $1 \times 10^{-6} \mathrm{~W} \mathrm{~m}^{-2}$ \\
\hline \multicolumn{3}{|c|}{ Creep parameters for Granite } \\
\hline$n_{G}$ & power law exponent & 3.3 \\
\hline$Q_{G}$ & activation energy & $186.5 \mathrm{~kJ} \mathrm{~mole}^{-1}$ \\
\hline$A_{G}$ & initial constant & $3.16 \times 10^{-26} \mathrm{~Pa}^{-n} \mathrm{~s}^{-1}$ \\
\hline \multicolumn{3}{|c|}{ Creep parameters for Diabase } \\
\hline$n_{D}$ & power law exponent & 3.05 \\
\hline$Q_{D}$ & activation energy & $276 \mathrm{~kJ} \mathrm{~mole}^{-1}$ \\
\hline$A_{D}$ & initial constant & $3.2 \times 10^{-20} \mathrm{~Pa}^{-n} \mathrm{~s}^{-1}$ \\
\hline \multicolumn{3}{|c|}{ Creep parameters for Dry Olivine } \\
\hline$n_{O}$ & power law exponent & 3.0 \\
\hline$Q_{O}$ & activation energy & $510 \mathrm{~kJ} \mathrm{~mole}^{-1}$ \\
\hline$A_{O}$ & initial constant & $7 \times 10^{-14} \mathrm{~Pa}^{-n} \mathrm{~s}^{-1}$ \\
\hline
\end{tabular}

4.1 Boundary conditions, constraints and reference model description

The initial conditions for the modelling can be constrained by considering the pre-rift crust and lithosphere thickness and the initial width of the deforming zone. It is generally as- 
Table 2. Model scenarios for Pannonian Basin

\begin{tabular}{cccc}
\hline Models & $\begin{array}{c}\text { Amount of } \\
\text { Extension, } \\
\mathrm{km}\end{array}$ & $\begin{array}{c}\text { Extension } \\
\text { Duration, } \\
\mathrm{Ma}\end{array}$ & Velocity, \\
$\mathrm{m} \mathrm{s}^{-1}$ \\
\hline 1 & 100 & 3.5 & $9.2 \times 10^{-10}$ \\
2 & 150 & 6.0 & $8.0 \times 10^{-10}$ \\
3 & 100 & 8.0 & $4.0 \times 10^{-10}$ \\
\hline
\end{tabular}

sumed that previous to the extensional history the Pannonian crust and lithosphere had been thickened (Horvát, 1993). The pre-rift crustal thickness is reasonably well constrained to be in the order of 40 to $45 \mathrm{~km}$ (van Balen and Cloetingh, 1995), the pre-rift lithosphere thickness is less well constrained and may range from 120 to $200 \mathrm{~km}$. The pre-rift width in E-W direction of the zone that experienced lithosphere thinning and basin formation, e.g. the zone between the Eastern Alps and the Apuseni Mts., is in the order $200-350 \mathrm{~km}$.

The velocity and timing of extension is not very well constrained. The first passive rift event is dated to have lasted from 17.5 to 14.0 Ma (Horvát, 1993). Strong mantle lithosphere thinning and the second rift phase occurred 6 to $8 \mathrm{Ma}$ following the initiation of the rift around 11.58(?) Ma before Present. Balancing of the East-Carpathians has shown (Ellouz and Roca, 1994) that 100 to $150 \mathrm{~km}$ of eastward movement occurred in the late Early Miocene to Late Miocene between 17.5 and 14-9.5 Ma before Present (Ellouz and Roca, 1994). Three distinct scenarios where modelled in which the duration and amount of extension where varied (Table 2).

\subsection{Description of the reference models}

All of the models are characterised by a crustal thickness of $35 \mathrm{~km}$ and in the absence of good constraints on the thickness of lithosphere each of the models has been run with a $120 \mathrm{~km}$ thick and with a $150 \mathrm{~km}$ thick lithosphere.

In the centre of the models a $300 \mathrm{~km}$ wide zone of the crust has been thickened to $45 \mathrm{~km}$, representing the pre-rift thickened crust (Fig. 10). A constant asthenosphere temperature of $T_{a}=1300^{\circ} \mathrm{C}$ is applied at the bottom of the lithosphere. It is assumed that the pre-rift lithosphere was thermally equilibrated. After the relevant amount of extension has been reached boundary velocities were lowered one order of magnitude decreasing the amount of subsequent, far-field related, post-rift extension to a minimum. Characteristics of the crust and lithosphere configuration of the reference models are given in Table 3. To facilitate a comparison with the Pannonian basin history the models start at 17.5 Ma before Present and evolve until $0 \mathrm{Ma}$.
Table 3. Setup reference models

\begin{tabular}{ll}
\hline Parameter & value \\
\hline Length of model $x_{L}$ & $1000 \mathrm{~km}$ \\
Depth base upper crust $h_{u c}$ & $15 \mathrm{~km}$ \\
Depth base upper crust $h_{l c}$ & $35 \mathrm{~km}$ \\
Depth base mantle lithosphere $h_{m}$ & $120 \mathrm{or} 150 \mathrm{~km}$ \\
Thickened crust & $45 \mathrm{~km}$ \\
Width of thickened zone & $300 \mathrm{~km}$ \\
Temperature at the base $T_{\text {base }}$ & $1300^{\circ} \mathrm{C}$ \\
\hline
\end{tabular}

\section{Modelling results}

\subsection{Model 1A: $100 \mathrm{~km}$ extension from 17.5 to $14 \mathrm{Ma} \mathrm{BP}$,} normal $120 \mathrm{~km}$ lithosphere

In Models $1 \mathrm{~A}$ and $1 \mathrm{~B}$ a total amount $100 \mathrm{~km}$ of extension takes place between 17.5 and $14 \mathrm{Ma}$ before Present. This results in a boundary velocities of $9.2 \times 10^{-10} \mathrm{~m} \mathrm{~s}^{-1}$ during a period of 3.5 Ma. The model represents a situation in which most of the far-field driven extension takes place during the first rift phase.

Fig. 11a shows the initial situation. Stress concentration has taken place in the upper crustal layers and in the upper part of the mantle lithosphere. A large reservoir of weak lower crust exist in the centre of the model due to the crustal thickening. It should be stressed that the thermal anomaly in the model is completely due to the increased heat production related to crustal thickening.

At the end of the syn-rift, at $14 \mathrm{Ma}$ before Present (Fig. 11b), a $150 \mathrm{~km}$ wide surface depression and $200 \mathrm{~km}$ wide broad upwelling of the asthenosphere have developed. Subsidence of the centre of the basin area is in the order of $1700 \mathrm{~m}$, whereas the asthenosphere diapir has risen $24 \mathrm{~km}$. Significant thermal advection has taken place. Total extension amounts to $100 \mathrm{~km}$. The crust has been thinned by a moderate thinning factor $\beta=1.25$, whereas the mantle lithosphere has been thinned by a factor of $\delta=2.0$.

Subsequently, boundary velocities are lowered one order of magnitude, limiting further far-field extension to a minimum. In the following interval the dome continues to rise an additional 3-4 km with much lower velocity. At $0 \mathrm{Ma}, 17 \mathrm{Ma}$ following the start of rifting (Figs. $11 \mathrm{~b}$ and 11c), total crustal thinning amounts to $\beta=1.3$, whereas the mantle lithosphere has been thinned by a factor of $\delta=2.5$. A peak rise velocity of the convective upwelling of $5400 \mathrm{~m} / \mathrm{Ma}$ is reached $1 \mathrm{Ma}$ after the initiation of the rift. The crust and mantle thinning pattern (Figs. 11b and 11c) shows that during the synrift crustal thinning is linearly increasing with time, whereas mantle lithosphere thinning shows a non-linear increase of the thinning factor. This can be interpreted as the increasing importance of the convective upwelling with increasing perturbation due to the passive rift event. Further focussing of 
(a)
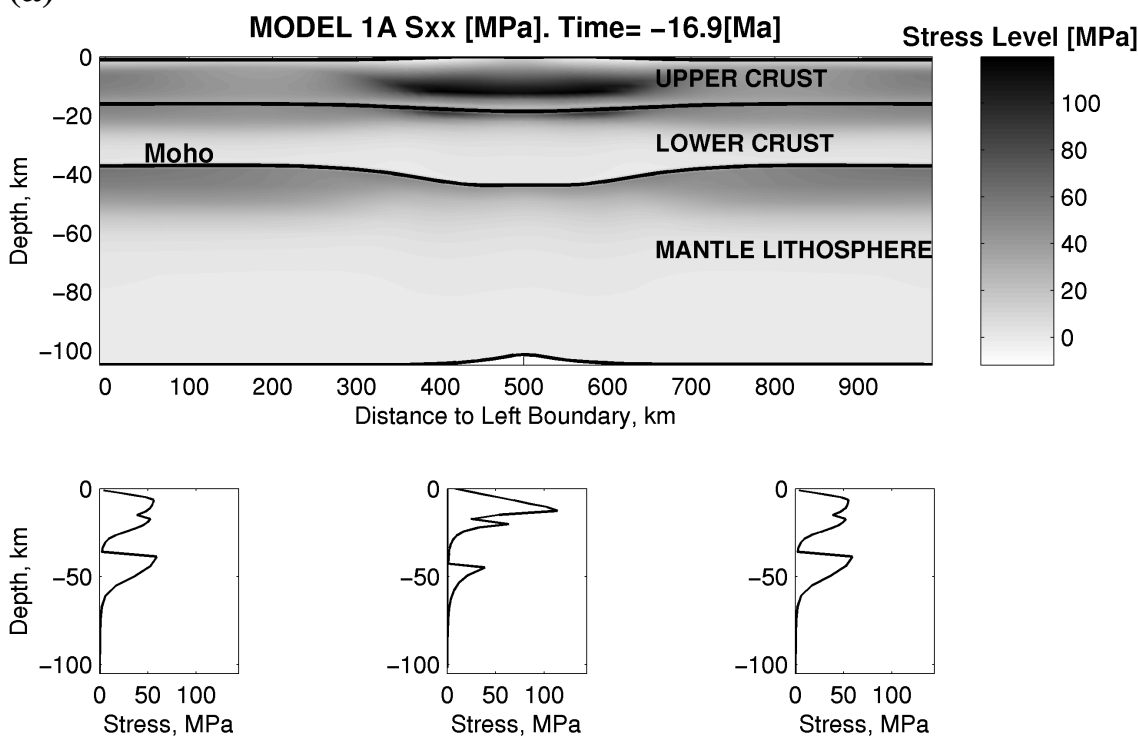

(b)
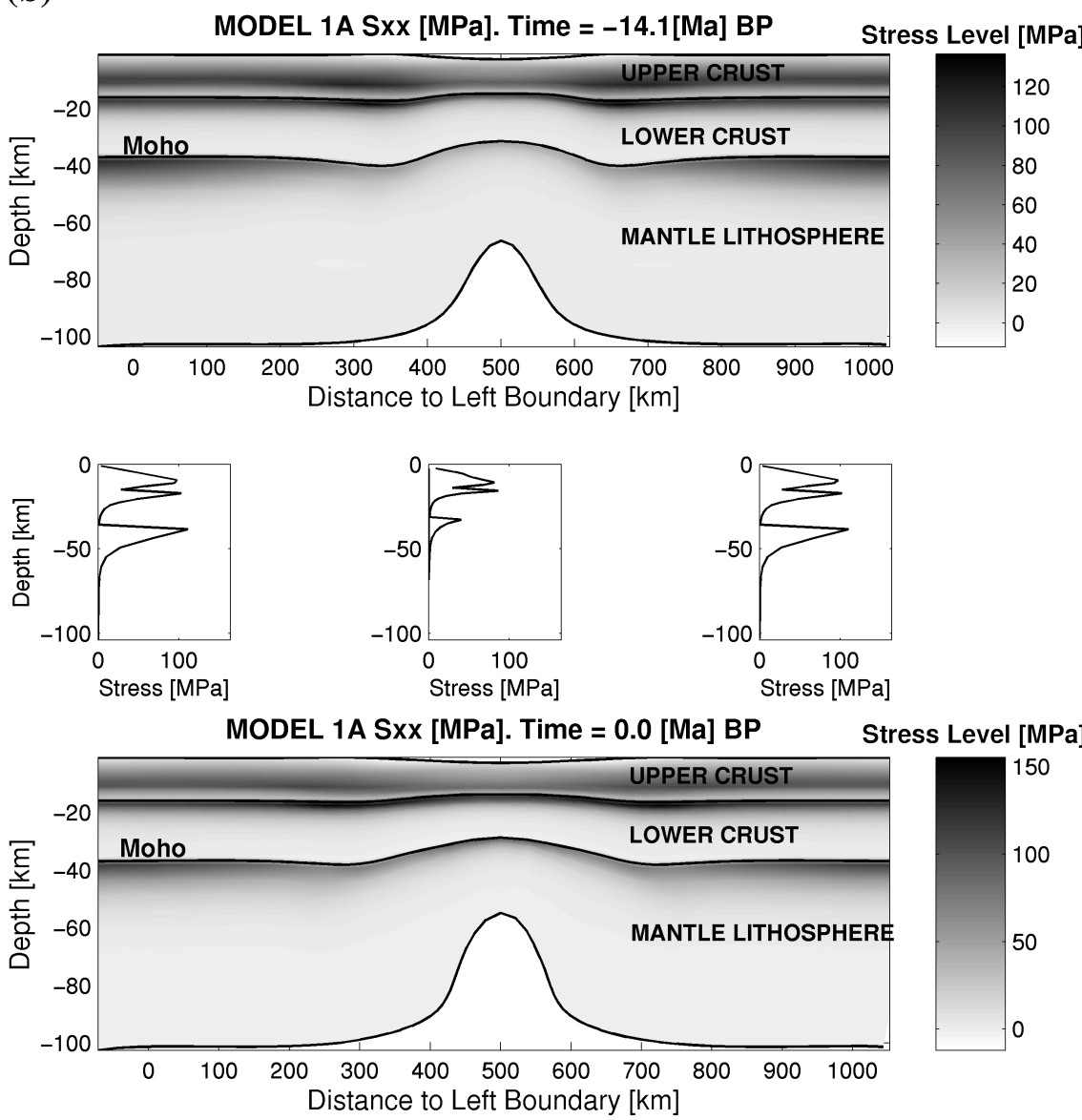

Fig. 11a. Model 1A: (a) Horizontal deviatoric stress at 16.9 Ma before Present, i.e. 0.6 Ma after the model start. Note stress concentration in crustal layers above the weak mantle lithosphere in the central part of the model. The thermal anomaly is completely due to increased heat production in the thick crust in the centre. (b) Horizontal deviatoric stress at $14 \mathrm{Ma}$ (upper panel) and at $0 \mathrm{Ma}$ (lower panel). At $14 \mathrm{Ma}$ far-field velocity is reduced one order of magnitude decreasing further far-field related extension to a minimum. In the subsequent "post-rift", additional rise of the mantle lithosphere to $55 \mathrm{~km}$ takes place. (c) Basin subsidence, asthenospheric rise, crust and mantle lithosphere thinning and rise velocity of the asthenosphere diapir in the centre of the model are given in the upper panels. The lower panel gives crust and mantle lithosphere thinning over the model (Fig. 11 continues). 

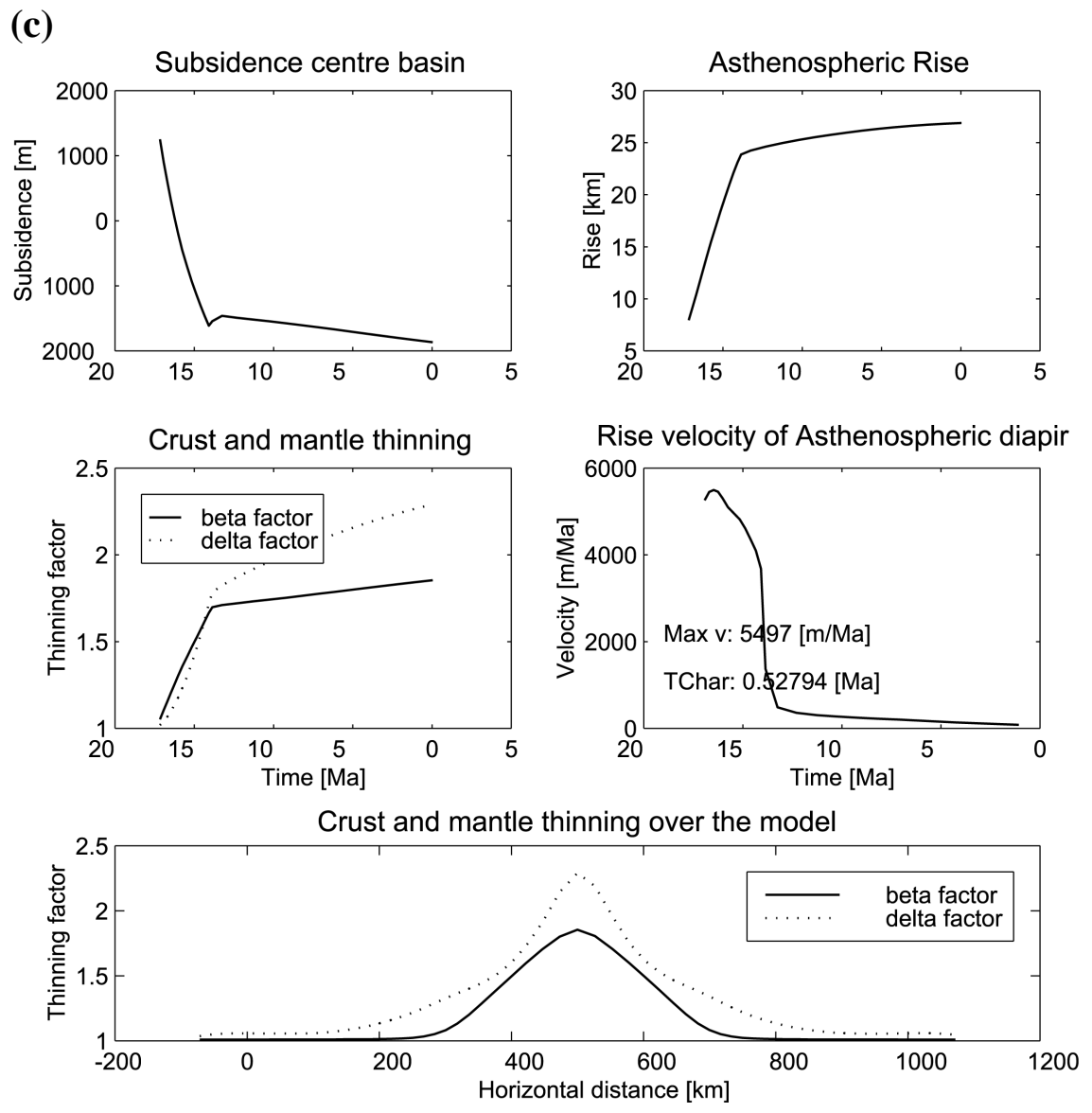

Fig. 11c. ... continued.

the asthenosphere upwelling occurs during the post rift evolution as the asthenosphere diapir is still in its active stage.

\subsection{Model 1B: $100 \mathrm{~km}$ extension between $17.5 \mathrm{Ma}$ and $14 \mathrm{Ma}, 150 \mathrm{~km}$ thick lithosphere}

In this model the thickness of the lithosphere has been increased to $150 \mathrm{~km}$. Increasing the thickness of the mantle lithosphere has the effect of increasing the buoyancy forces and with this the potential small-scale convective instability of the system.

In Fig. 12a the situation at $14 \mathrm{Ma}$ and at $0 \mathrm{Ma}$ before Present is shown. The total amount of crustal thinning is of the same order as in the previous model whereas asthenospheric diapirism and the amount of additional post-rift asthenospheric rise have increased. At the end of the synrift stage the crust has extended by a factor $\beta=1.3$. The mantle lithosphere has been thinned by a factor of $\delta=2.2$ (Fig. 12b).

At $0 \mathrm{Ma}$ total subsidence in the centre of the model is $1800 \mathrm{~m}$, whereas the asthenosphere has risen $40 \mathrm{~km}$. In the post-rift the asthenosphere rises an additional $7-8 \mathrm{~km}$, with a total mantle lithosphere thinning at $0 \mathrm{Ma}$ of $\delta=3.0 \mathrm{com}$ pared with $\delta=2.5$ in model 1A (Fig. 11c). The astheno- spheric dome obtains its peak rise velocity $7645 \mathrm{~m} / \mathrm{Ma}$ at $2.3 \mathrm{Ma}$ following the initiation of the rift. The peak rise velocity is higher but obtained later then in the previous model. This shows the effect of increased buoyancy forces which increase the rise velocity and the effect of the slightly colder thermal conditions due to thickening of the lithosphere which slightly delays the acceleration of the diapir.

\subsection{Model 2A: $150 \mathrm{~km}$ extension between 17.5 and 11.5 Ma, normal $120 \mathrm{~km}$ thick lithosphere}

In Models 2A and 2B the total amount of $150 \mathrm{~km}$ of extension takes place during a period of $6.0 \mathrm{Ma}$. In comparison with the previous model this model is characterised by more extension taking place during a longer time interval at a similar velocity. The boundary velocities are 8.0 times $10^{-10} \mathrm{~m} \mathrm{~s}^{-1}$ during a period of 6.0 Ma. This model represents a situation in which most of the far-field driven extension takes place between 17.5 and $11.5 \mathrm{Ma}$ before Present.

In Fig. 13a the situation is shown at $11.5 \mathrm{Ma}$ and at $0 \mathrm{Ma}$ before Present. At 11.5 Ma asthenospheric upwelling as well as crustal thinning are well developed. A relative narrow upwelling with a width of $200 \mathrm{~km}$ together with broad Moho updoming can be observed. Crustal thinning is in the order 
(a)
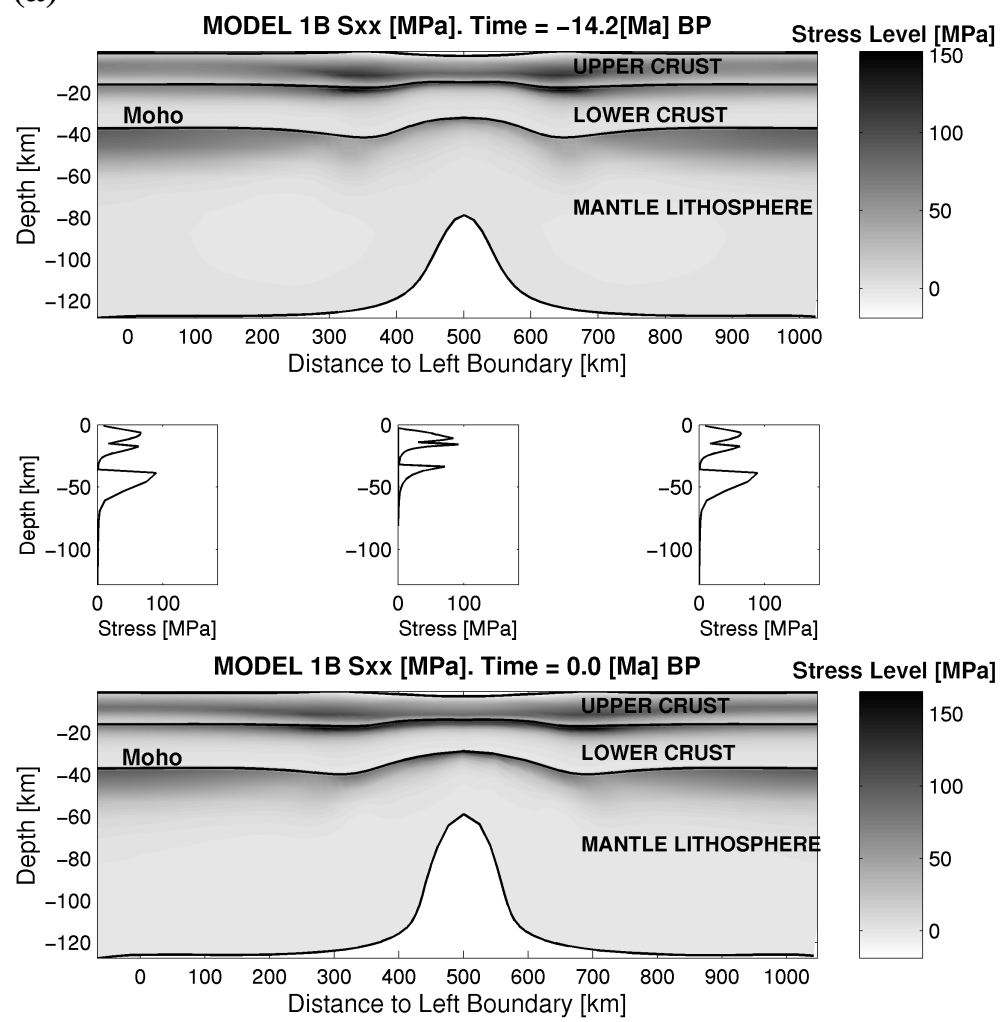

(b)
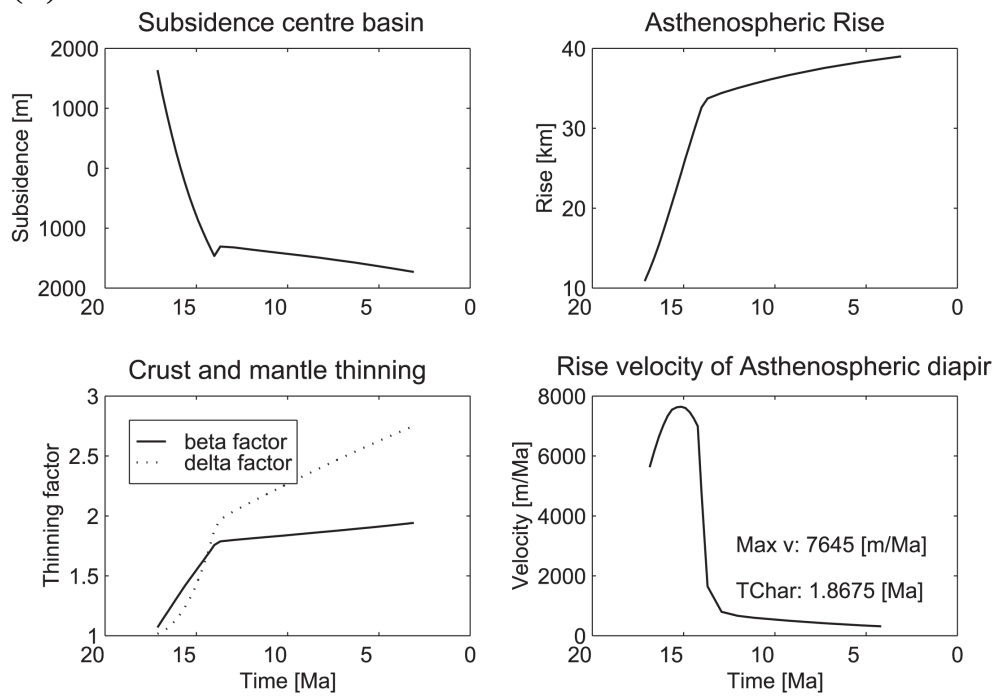

Crust and mantle thinning over the model

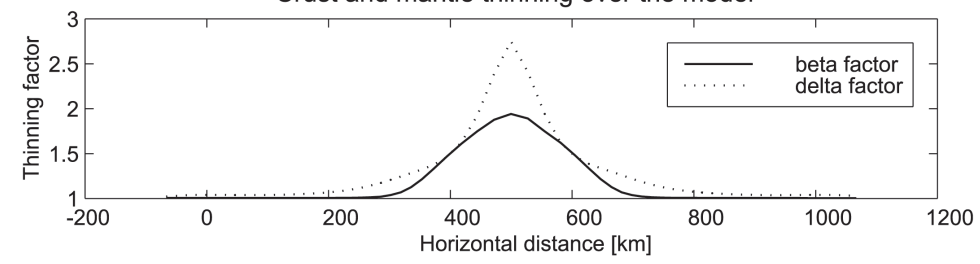

Fig. 12. Model 1B: (a) Horizontal deviatoric stress at 14.1 Ma BP and at $0 \mathrm{Ma}$. At $14 \mathrm{Ma}$ far-field velocity is reduced one order of magnitude decreasing further far-field related extension to a minimum. (b) Basin subsidence, asthenospheric rise, crust and mantle lithosphere thinning and rise velocity of the asthenosphere diapir in the centre of the model are given in the upper panels. The lower panel gives crust and mantle lithosphere thinning over the model. 

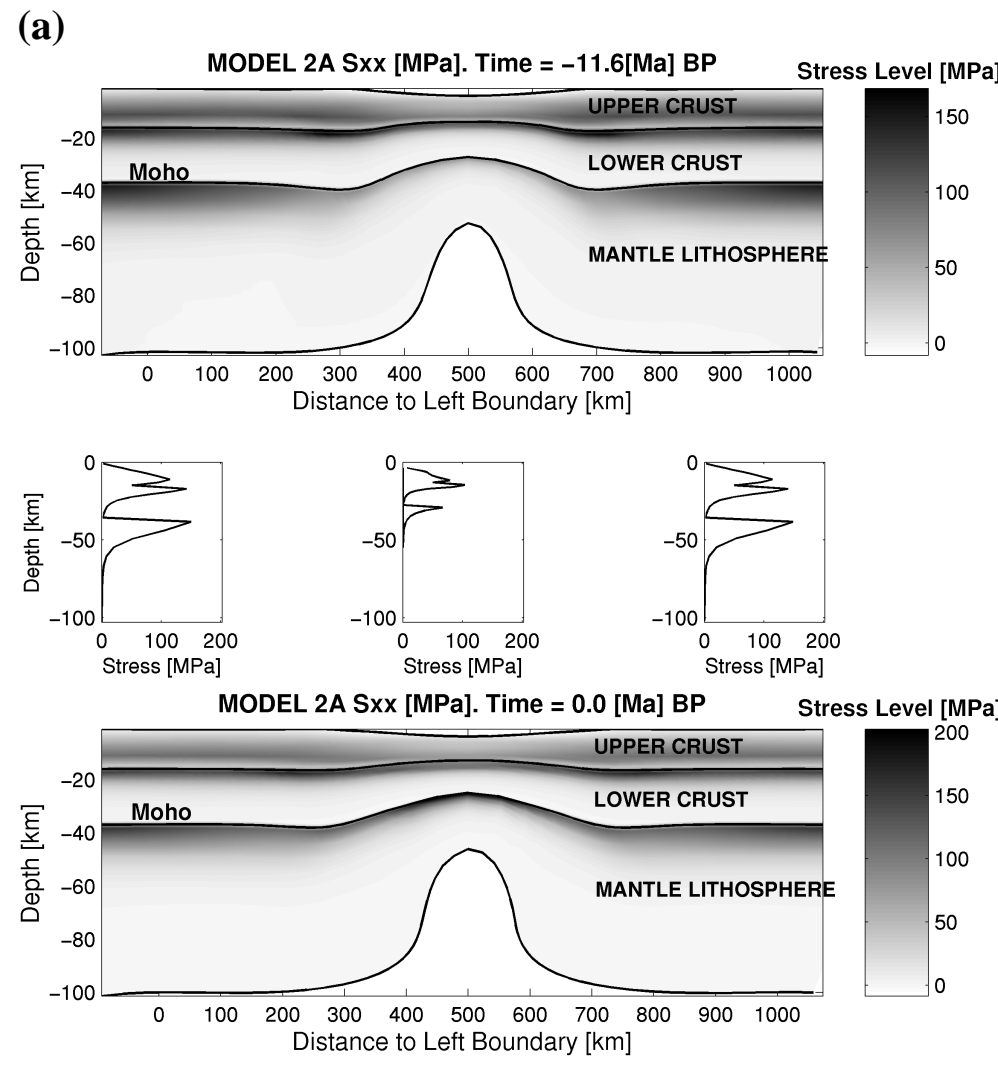

(b)
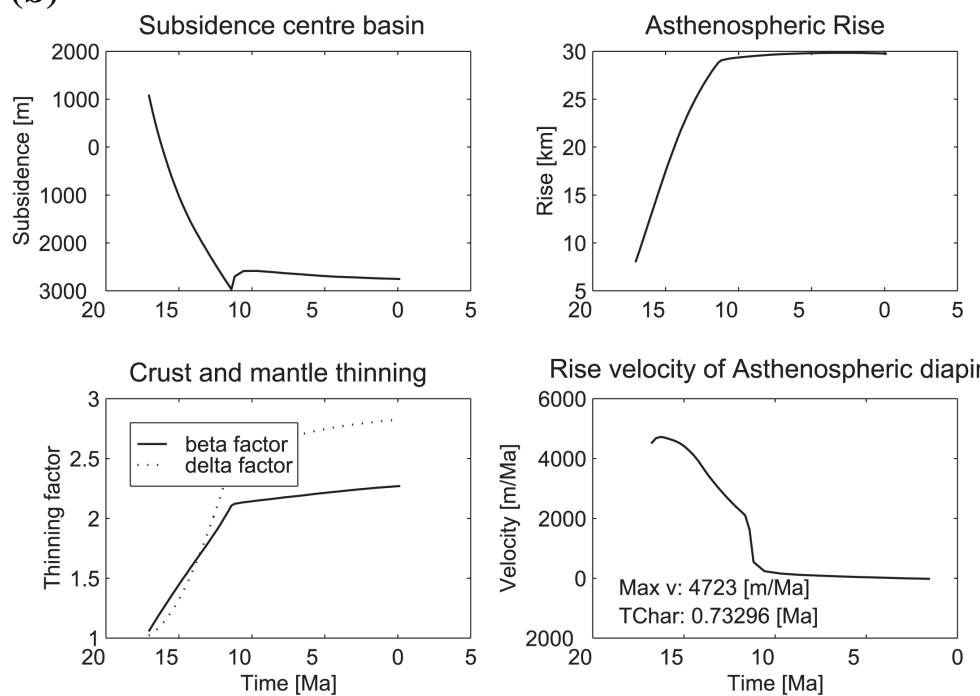

Crust and mantle thinning over the model

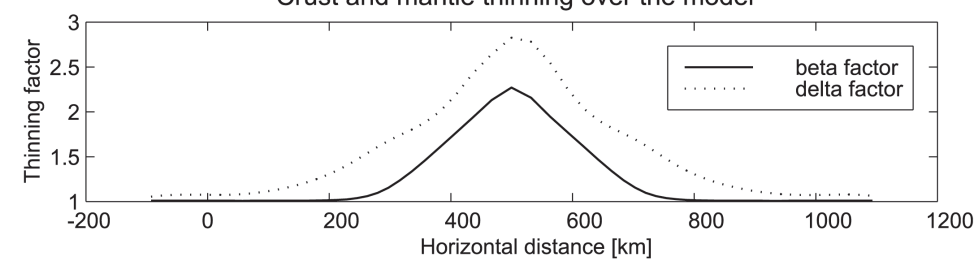

Fig. 13. Model 2A: (a) Horizontal deviatoric stress at 11.5 Ma BP and at $0 \mathrm{Ma}$. (b) Basin subsidence, asthenospheric rise, crust and mantle lithosphere thinning and rise velocity of the asthenosphere diapir in the centre of the model are given in the upper panels. The lower panel gives crust and mantle lithosphere thinning over the model. 
(a)
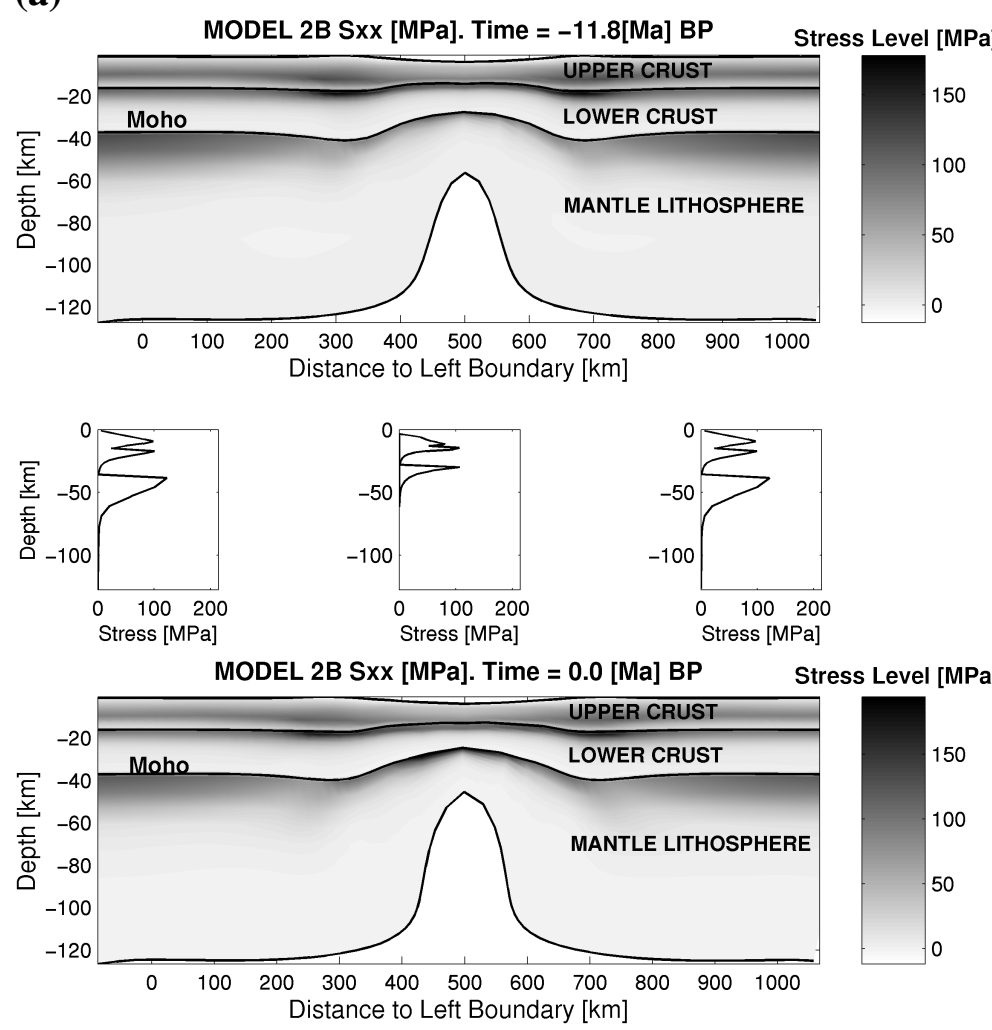

(b)
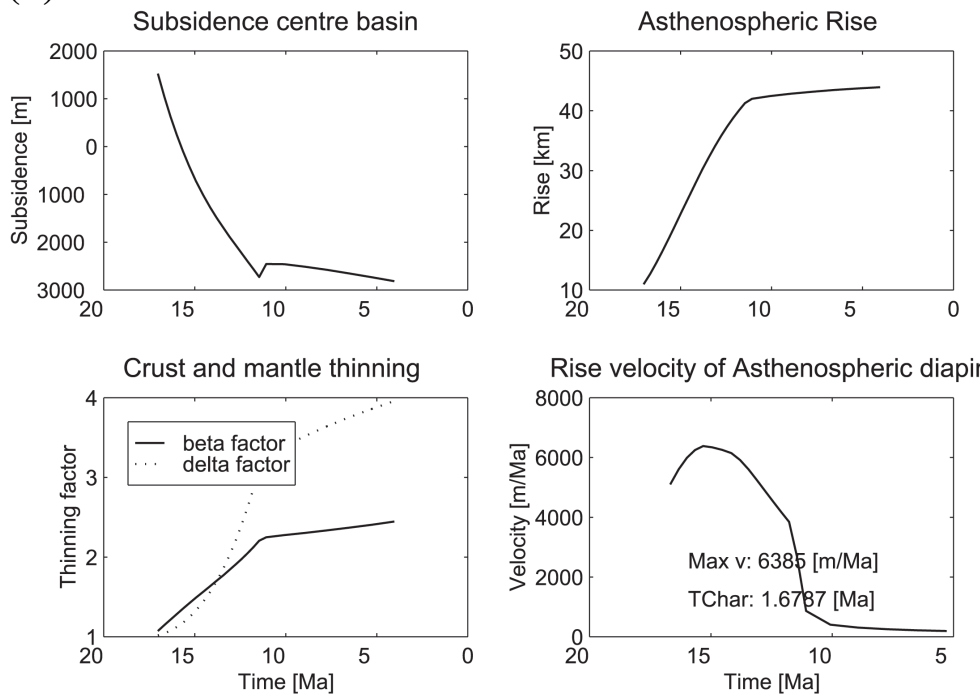

Crust and mantle thinning over the model

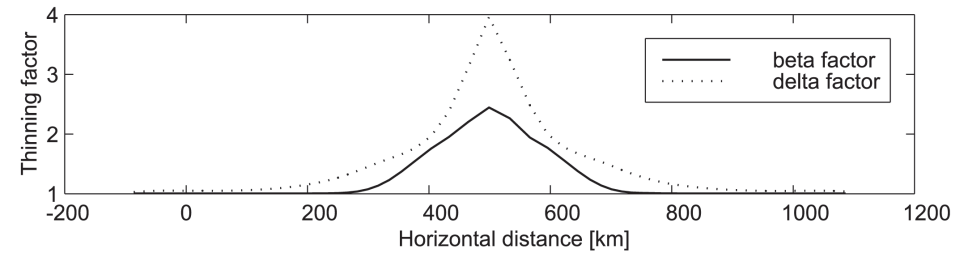

Fig. 14. Model 2B: (a) Horizontal deviatoric stress at 11.5 Ma BP and at $0 \mathrm{Ma}$. (b) Basin subsidence, asthenospheric rise, crust and mantle lithosphere thinning and rise velocity of the asthenosphere diapir in the centre of the model are given in the upper panels. The lower panel gives crust and mantle lithosphere thinning over the model. 
of $\beta=1.6$, whereas the mantle lithosphere is thinned by a factor $\delta=2.8$ (Fig. 13b). The centre of the basin has subsided to a depth of $3000 \mathrm{~m}$, whereas the asthenosphere has risen $30 \mathrm{~km}$.

At $0 \mathrm{Ma}$ BP only moderate additional thinning has affected the mantle lithosphere and the crust. Since most of the possible small-scale convective asthenosphere upwelling occurred already during the syn-rift, only minor additional rise has taken place in the post-rift evolution. The maximum asthenospheric rise velocity of $4720 \mathrm{~m} / \mathrm{Ma}$ is obtained $1.2 \mathrm{Ma}$ after the initiation of the rift zone.

5.4 Model 2B: $150 \mathrm{~km}$ extension between 17.5 and 11.5 Ma, $150 \mathrm{~km}$ thick lithosphere

In this model the lithosphere thickness has been increased to $150 \mathrm{~km}$. Again the velocity and amount of asthenosphere upwelling are higher then in the previous model due to the larger buoyancy forces.

The situation at $11.5 \mathrm{Ma}$ and at $0 \mathrm{Ma}$ is shown in Fig. 14a. At $11.5 \mathrm{Ma}$, crust and mantle thinning factors are respectively $\beta=1.65$ and $\delta=3.5$. The asthenosphere has risen $40 \mathrm{~km}$ and the basin has subsided to a depth of $2700 \mathrm{~m}$. Mantle lithosphere thinning accelerates during the syn-rift stage and starts to deviate from the crustal thinning around $13.5 \mathrm{Ma}$ (Fig. 14b). At 11.5 Ma, when the extensional boundary velocity is lowered one order of magnitude, rise velocity drops. However, since there is still accommodation space for the asthenospheric diapir in the upper part of the mantle lithosphere, upwelling continues. At 3.5 Ma BP mantle lithosphere thinning has increased to $\delta=4.2$, whereas crustal thinning has only increased by a minor amount to $\beta=1.7$ (Fig. 14b). The final morphology of the rift shows a relative narrow focused asthenospheric upwelling with a wavelength of $150-200 \mathrm{~km}$ and $200 \mathrm{~km}$ wide surface depression.

5.5 Model 3A: $100 \mathrm{~km}$ extension between 17.5 and 9.5 Ma, normal $120 \mathrm{~km}$ thick lithosphere

In models $3 \mathrm{~A}$ and 3B a total amount of $100 \mathrm{~km}$ of extension takes place during a period of $8 \mathrm{Ma}$. The only difference with models $1 \mathrm{~A}$ and $1 \mathrm{~B}$ is the lower velocity at which the extension takes place. The resulting boundary velocity is $4.0 \times 10^{-10} \mathrm{~m} \mathrm{~s}^{-1}$ during a period of $8 \mathrm{Ma}$. This model represents a situation in which far-field driven extension takes place during the first and second rift phase between 17.5 and 9.5 Ma before Present.

At 9.5 Ma a wide, $1200 \mathrm{~m}$ deep, surface depression and an asthenosphere upwelling with an amplitude of $23 \mathrm{~km}$ have developed (Fig. 15a). At this stage crustal and mantle lithosphere thinning respectively are in the order $\beta=1.3$ and $\delta=2.0$ (Fig. 15b). During the subsequent rift history additional 4-6 km of asthenosphere upwelling increases mantle lithosphere thinning to $\delta=2.5$, whereas only minor additional thinning has affected the crustal layers. A maximum asthenosphere rise velocity of $2308 \mathrm{~m} / \mathrm{Ma}$ is reached at 3.35 Ma following the initiation of the rift zone. The crustal layers show minor thickening (i.e. $\beta<1$ ) beneath the rift flanking regions.

\subsection{Model 3B: $100 \mathrm{~km}$ extension between 17.5 and $9.5 \mathrm{Ma}$, $150 \mathrm{~km}$ thick lithosphere}

Again lithosphere thickness is increased to $150 \mathrm{~km}$. The situation at $9.5 \mathrm{Ma}$ and at $0 \mathrm{Ma}$ is shown in Fig. 16a. Similarly, as in the results of model $1 \mathrm{~B}$ and $2 \mathrm{~B}$ the amount and velocity of mantle lithosphere thinning increase with respect to the situation of a $120 \mathrm{~km}$ thick lithosphere.

Here, at 9.5 Ma before Present the mantle lithosphere and the crust have been thinned by an amount of $\delta=2.1$ and $\beta=1.25$ (Fig. 16b). In the subsequent post-rift evolution additional thinning to $\delta=3.0$ and $\beta=1.3$ takes place. Post-rift additional rise of the asthenosphere in this model amounts to $6-8 \mathrm{~km}$. The plot of the rise velocity shows that at $0 \mathrm{Ma}$ before Present the asthenospheric upwelling did not yet reach its limiting isotherm and will continue moving upwards.

\subsection{Model inferences}

As shown, in each of the different model scenarios it is possible to reach a final crust-lithosphere configuration which is reasonable similar to the observations. Several conclusions may be drawn from the model results. The amount of crustal thinning is direct proportional to the amount of far-field extension with similar $\beta$ values for model 1 and 3 . Two factors determine the amount of mantle lithosphere thinning, i.e. a component of far-field extension related passive necking and a component of buoyancy driven asthenosphere doming. The relative contribution of these two components depends on the efficiency of the buoyancy driven flow, which is in term dependent on the temperature of the asthenosphere, the thickness of the lithosphere and the size of the thermal perturbation of the mantle lithosphere.

On the base of the geological evolution models $1 \mathrm{~A}$ and $1 \mathrm{~B}$ provide the most reasonable scenarios. Here most of the far-field driven extension takes place during the synrift phase whereas substantial additional asthenospheric rise takes place in the post-rift evolution. The crustal thinning factors predicted by the models $1 \mathrm{~A}$ and $1 \mathrm{~B}$ compare reasonably well with those resulting from the kinematic modelling studies, i.e. $\beta_{\text {model }}=1.7$ compared to $\beta_{\text {observed }}=1.5$. $\mathrm{Al}-$ though the models show significant differential thinning of the mantle lithosphere, the models underpredict thinning of the mantle lithosphere when compared to values obtained for the Pannonian basin, i.e. $\delta_{\text {model }}=2.5$ to 4 compared to $\delta_{\text {observed }}=4$ to 8 . Models with a $150 \mathrm{~km}$ thick lithosphere predict higher mantle lithosphere thinning then those with a $125 \mathrm{~km}$ thick lithosphere and provide a better match. There may be several reasons for this discrepancy. First of all in using dry olivine for the mantle lithosphere we have chosen a very conservative rheology (i.e. strong). This decreases the low viscous region of the mantle lithosphere which can participate in buoyancy driven flow. Second, the possible 
(a)
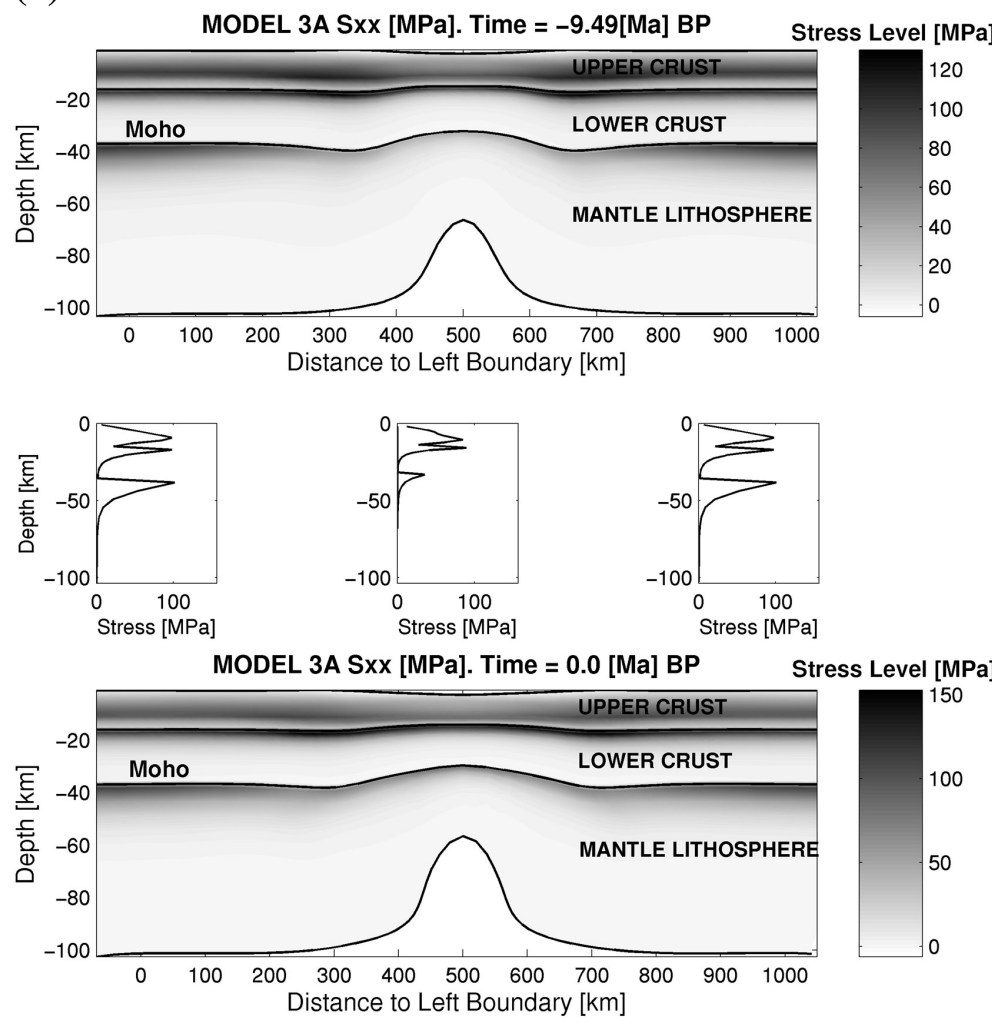

(b)
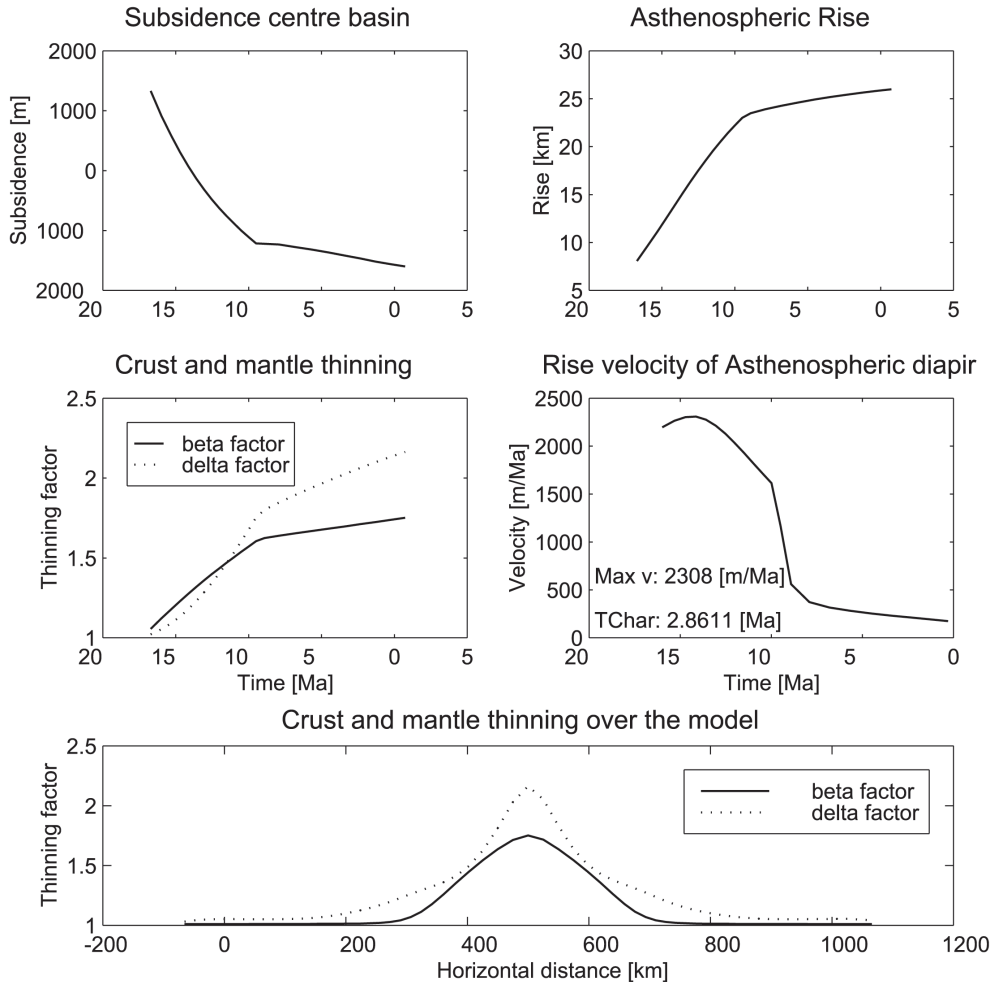

Fig. 15. Model 3A: (a) Horizontal deviatoric stress at $9.5 \mathrm{Ma} \mathrm{BP}$ and at $0 \mathrm{Ma}$. (b) Basin subsidence, asthenospheric rise, crust and mantle lithosphere thinning and rise velocity of the asthenosphere diapir in the centre of the model are given in the upper panels. The lower panel gives crust and mantle lithosphere thinning over the model. 

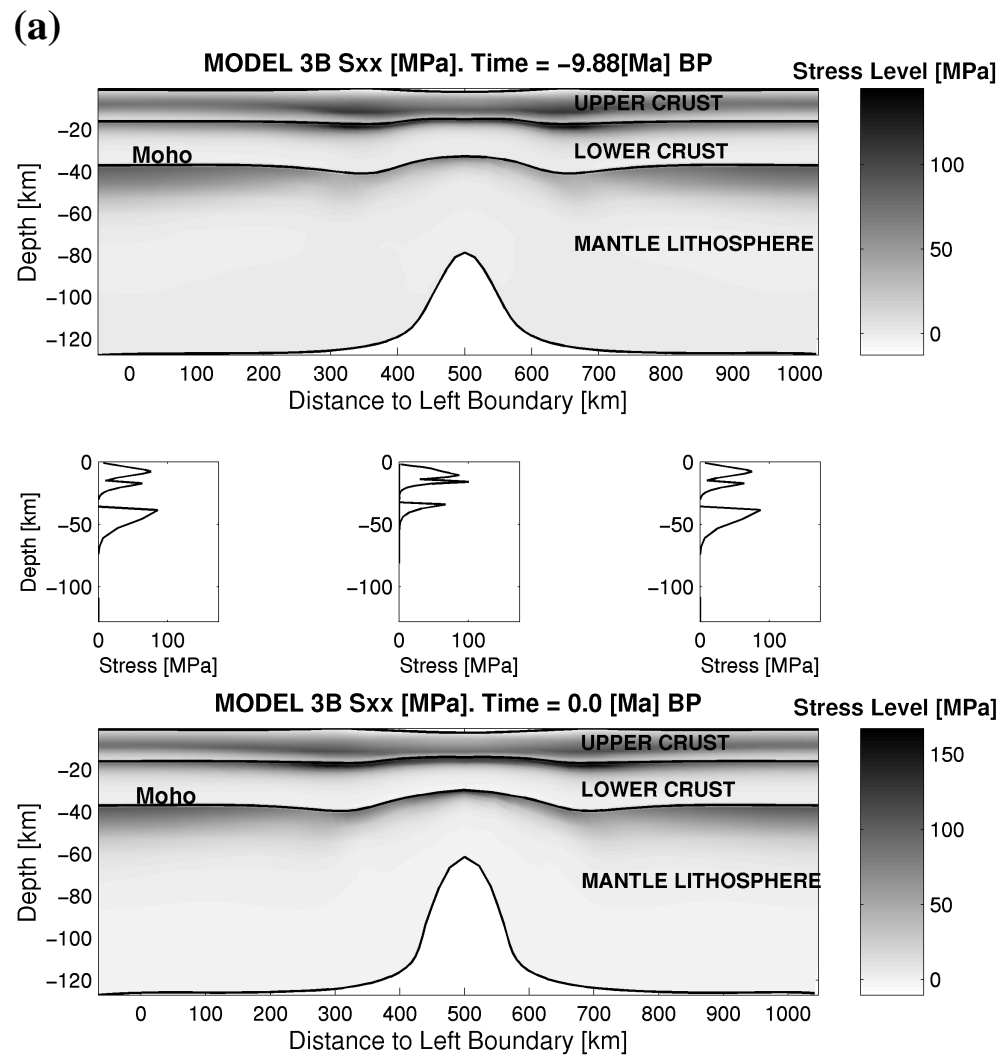

(b)
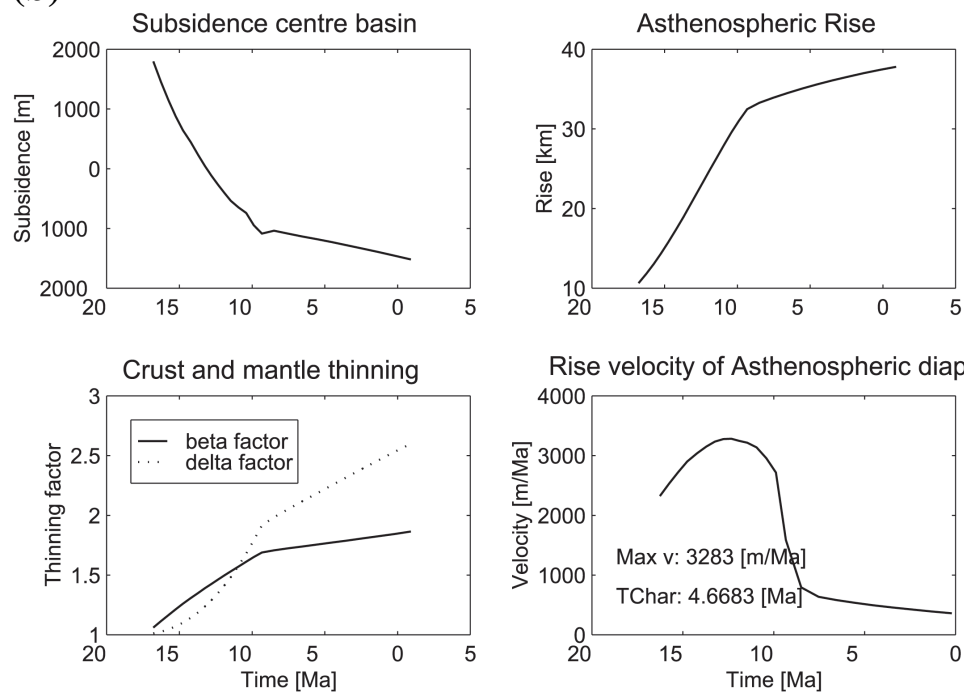

Rise velocity of Asthenospheric diapir

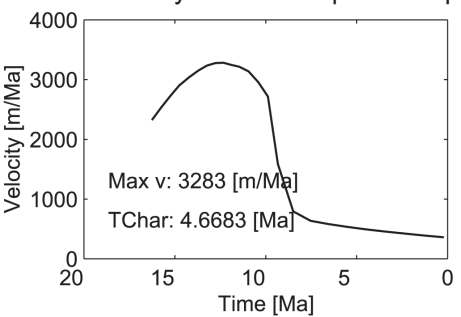

Crust and mantle thinning over the model

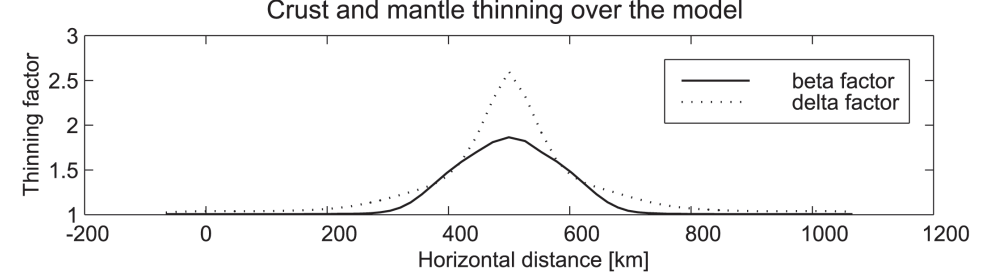

Fig. 16. Model 3B: (a) Horizontal deviatoric stress at $9.5 \mathrm{Ma} \mathrm{BP}$ and at $0 \mathrm{Ma}$. (b) Basin subsidence, asthenospheric rise, crust and mantle lithosphere thinning and rise velocity of the asthenosphere diapir in the centre of the model are given in the upper panels. The lower panel gives crust and mantle lithosphere thinning over the model. 
a) Middle Miocene

Overall extension in the Upper Plate

Pannonian basin Transylvanian basin E Carpathians

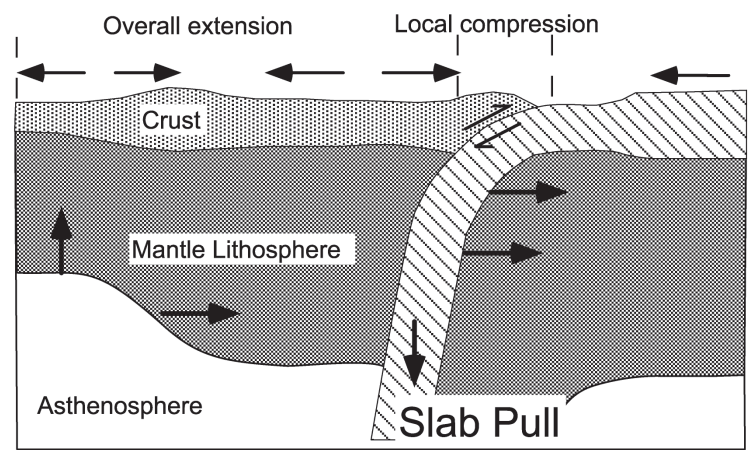

W b) Late Miocene - Pliocene

Extension coeval with climax Compression

Pannonian basin Transylvanian basin E Carpathians

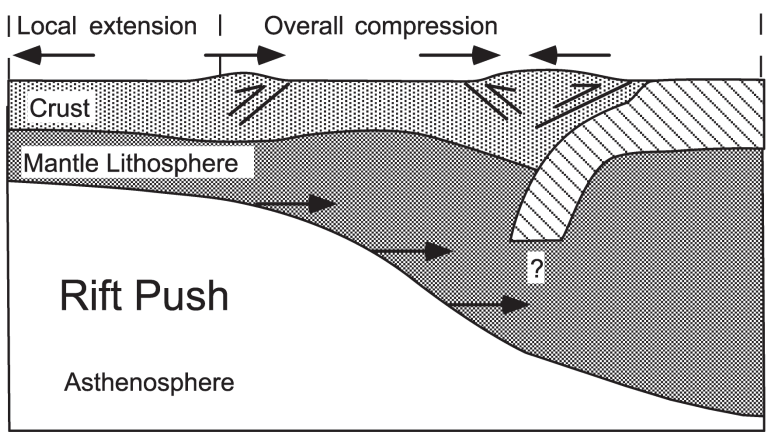

W

Fig. 17. Cartoon of the two-stage development of the Pannonian basin system. (a) Middle Miocene overall extension, first rift phase dominated by the effects of slab roll-back related back arc extension. (b) Late Miocene-Pliocene coeval extension and compression, dominated by the effects of rift-push forces generating local extension and regional compression.

effects of decompression melting are not included in the model. Melts may, as previously suggested (Stegena et al., 1975; Royden et al., 1983b), form an additional mechanism to weaken and thin the mantle lithosphere and would enhance the buoyancy driven flow. The constraints on the exact timing and amount of E-W directed extension do not justify a further fitting of the model to the Pannonian basin, which is also not realistic given the large uncertainties in the rheological parameters and the thermal condition. The model results, however, show that, using realistic rheological parameters and boundary conditions consistent with the Pannonian basin setting, the two-stage extensional evolution of the Pannonian basin can be explained by a first passive rift phase followed by a phase of small-scale convective upwelling of the asthenosphere.

\section{Discussion and conclusions}

6.1 The first rift phase: passive rifting due to back-arc extension

Following the observations and the criteria given above, it is likely that the first phase of extensive strike-slip and homogeneous extension is related to initiation of subduction and subsequent back-arc extension, as proposed by many authors (Stegena et al., 1975; Royden et al., 1983b; Horvát, 1993). The fact that the whole region towards the EastCarpathian arc experienced overall E-W extension with only local contractional accretionary wedge tectonics in the EastCarpathian arc indicates that subduction related back-arc extension is the dominant process during this time (Fig. 17a). As the pre-rift crust in the Pannonian region is thought to have had a moderately larger then normal thickness of around 40-45 km (van Balen and Cloetingh, 1995), gravitational collapse of the over thickened and thermally weakened crust in the Pannonian region may have assisted the overall east-west extension generated by the subduction system.

Analogue modelling of collision and subduction shows that shortening normal to an ocean-continent boundary may result in initiation of subduction accommodating extension normal to the contraction direction (Facenna et al., 1996). Movement is taken up along conjugate transpressive to transtensive fault systems giving way to oblique extension behind the subduction arc. This is very similar to the initiation of the Pannonian rift system which occurred along large conjugate transtensive fault systems. The subsequent occurrence of pure E-W extension in the Pannonian basin indicates the decreasing influence of N-S contraction due to the push of Adria compared to an increasing role for subduction related back-arc extension. Thus, the first rift event in the Pannonian basin is driven by passive driving forces resulting in moderate homogeneous thinning of the lithosphere.

6.2 The second rift phase and coeval mountain building in the East-Carpathians: small-scale convective upwelling related active rifting

Several models have been invoked to explain the late mantle lithosphere thinning during the second rift phase and the coeval climax of compression. A mantle plume can be ruled out since in this case alkaline volcanics and uplift are expected to precede the rift history which is in contradiction with the observations. The fact that mantle lithosphere thinning occurred late in the rift history suggests a relation to the previous rift history. Stegena et al. (1975) suggested that thermal erosion of the mantle lithosphere was accomplished by asthenospheric melts triggered by the fluids expulsed from the surrounding subduction zones. The small amounts of alkaline melts (Pecskay et al., 1995), however, contradict massive melting of the shallow asthenosphere and the lower litho- 
sphere. Therefore the intrusion of melts can only account for a minor amount of thinning of the mantle lithosphere.

The finite element modelling has shown that small-scale convective upwelling following a first phase of passive rifting may explain the late syn-rift to post-rift mantle lithosphere thinning in the Pannonian basin area. The model results show that the time scale and amount of asthenosphere upwelling in the Pannonian basin are consistent with a normal mantle temperature of $T_{a}=1300^{\circ} \mathrm{C}$. The thermal anomaly in the model provided by thick crust and by the thermal advection given by the first passive rift phase, drives the small-scale convective upwelling. It may be emphasised that no external heat source (e.g. mantle plume) is needed to drive the convective flow.

The coeval occurrence of the second rift phase with the strong mantle lithosphere upwelling suggests a causal relation between these two processes. If peak mantle thinning in the time interval of the inversion phase and the second rift phase, i.e. in the Late Miocene around 13-8(?) Ma, is indeed related to active asthenosphere upwelling, it is straightforward to connect the second rift phase to the dynamics of doming. This is not an unexpected relationship, since, as has been shown the buoyancy forces related to rifting generate a net extensional rift push force (Turcotte, 1983; Turcotte and Emerman, 1983; Le Pichon and Alvarez, 1984; Huismans et al., 2001a). Additionally, differential thinning of the lithosphere, implies a drastic increase of the rift push forces to the order of magnitude of plate driving forces. 3-dimensional modelling of the relative contribution of the buoyancy forces to the stress field confirms that at present rift push forces are dominant over the collapse forces in the Eastern Alps (Huismans et al., submitted manuscript, 2001). Since, it is logical to suppose that the rift push forces only decreased in time, it may be concluded that rift push forces related to the strong upwelling of the mantle lithosphere beneath the Pannonian basin provide the driving force for the second phase of extension (Fig. 17b).

A second reason to interpret rift push as the dominant force during this time interval is given by the stress and strain distribution for the Late Miocene-Early Pliocene. Most previous models suggested that the compressional and extensional forces in the Pannonian basin system are only related to subduction in the East-Carpathian arc and to the northward push of the Adriatic plate. These models, however, are unable to explain compressional stresses far in the overlying plate coeval with the second phase of extension. I.e. the Transylvanian basin, which forms the $200 \mathrm{~km}$ wide transition zone between the Pannonian basin and the East-Carpathian arc, is affected by strong contractional deformation during this time (Fig. 17b).

The main driving force for the compression must, therefore, be located in the Central Pannonian basin, e.g. in the area affected by strong mantle lithosphere upwelling at this time. This matches the expected stress and strain pattern for a situation dominated by rift push, which is given by local extension affecting the rifting area and overall compression affecting the region around it. Thus, the regional stress and

\section{Pannonian basin system evolution}
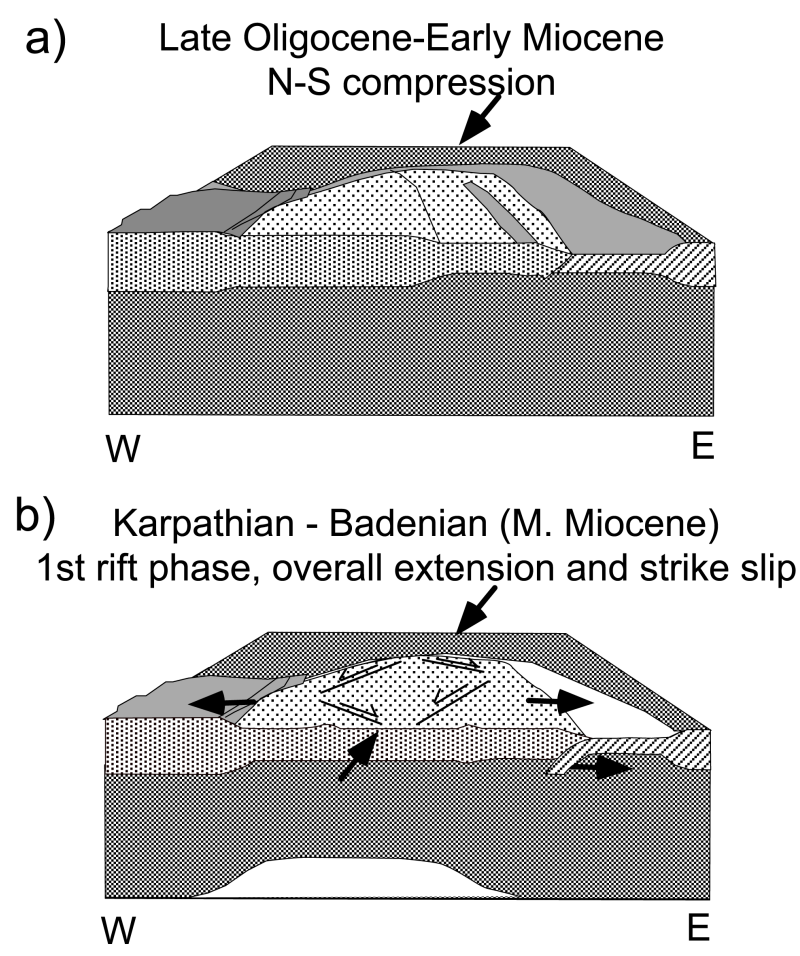

L) Late Miocene - Early Pliocene
2nd rift phase, climax of compression

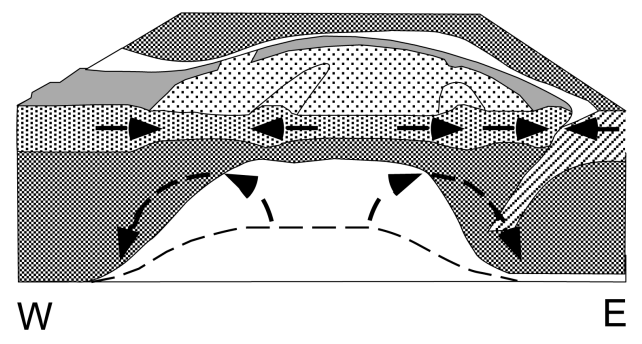

Fig. 18. 3D cartoon summarizing main elements of Pannonian basin system evolution. (a) Late Oligocene - Early Miocene N$\mathrm{S}$ compression, (b) Karpathian-Badenian first rift phase, overall extension and strike-slip related to initiation of subduction along the Carpathian arc and subsequent back-arc extension, (c) Late Miocene-Pliocene second rift-phase and coeval climax of compression in the East Carpathians and in the Eastern Alps related to active upwelling of the mantle lithosphere beneath the Pannonian basin.

strain pattern for the Late Miocene-Early Pliocene is consistent with the rift push forces being dominant over the forces related to the subduction in the East-Carpathian arc.

It can be concluded that the sequence of events which delineate the Neogene evolution of the Pannonian basin system can be very well understood in terms of the available driving forces for compressional as well as extensional tectonics. The first phase of extension can be understood in terms of the combined effects of subduction related backarc extension and extensional collapse of the overthickened 
crust of the Pannonian pre-rift lithosphere (Figs. 18a, b). The second phase of extension in the Pannonian basin associated with strong asthenosphere upwelling has been explained here in terms of small-scale convective upwelling of the mantle lithosphere triggered by the first rift event (Fig. 18c).

Acknowledgement. Claudio Facenna and Franz Neubauer are thanked for detailed and constructive reviews which helped improve the manuscript. Anco Lankreijer is thanked for permission to show subsidence analysis results for the Pannonian basin. Laszlo Csontos, Kurt Decker, Frank Horvát, Cestmir Tomek and Liviu Matenco are thanked for sharing their views on the Pannonian basin system and for stimulating discussions. R. S. Huismans thanks the Netherlands Organisation of Scientific Research (NWO) project nr. 751.360.003 for support of this work.

\section{References}

Balogh, K., Ebner, F., and Ravasz, C.: K/Ar Alter tertiärer Vulkanite der südöstlichen Steiermark und des südlichen Burgenlandes, in: Jubiläumsschrift 20 Jahre Geologische Zusammenarbeit Österreich-Ungarn,, Österreichische Mineralogische Gesellschaft, Wien, 2, 55-72, 1994.

Bergerat, F.: From pull-apart to the rifting process; the formation of the Pannonian basin, Tectonophysics, 157, 271-280, 1989.

Bergerat, F.: The Moesian platform as a piece for the understanding of the geodynamical evolution of the Carpatho-Balkan Alpine system, in: S.A.B. Crasquin-Soleau, E. (Ed.): Peri-Thetys Memoir 3: Stratigraphy and evolution of Peri-Thetyan platforms, Mem. Mus. natn. Hist. nat., 143-164, 1995.

Bird, P.: Finite element modeling of lithosphere deformation: the Zagros collision orogeny, Tectonophysics, 50, 307-336, 1978.

Buck, W. R.: When does small-scale convection begin beneath oceanic lithospere?, Nature, 313, 775-777, 1985.

Carter, N. L. and Tsenn, M. C.: Flow properties of continental lithosphere, Tectonophysics, 136, 27-63, 1987.

Chase, C. G.: Extension behind island arcs and motions relative to hotspots, J. Geophys. Res., 83, 5385-5387, 1978.

Csontos, L., Tari, G., Bergerat, F., and Fodor, L.: Evolution of the stress fields in the Carpatho-Pannonian area during the Neogene, Tectonophysics, 199, 73-91, 1991.

Csontos, L., Nagymarosy, A., Horvát, F., and Kováč, M.: Tertiary evolution of the intra-Carpathian area; a model, Tectonophysics, 208, 221-241, 1992.

Csontos, L.: Tertiary tectonic evolution of the Intra-Carpathian area: a review, Acta Vulcanologica, 7, 1-15, 1995.

Dobosi, G., Fodor, R. V., and Goldberg, S. A.: Late Cenozoic alkalic basalt magmatism in Northern Hungary and Slovakia: petrology, source compositions and relationships to tectonics, Acta Vulcanologica, 7, 199-208, 1995.

Downes, H. and Vaselli, O.: The lithospheric mantle beneath the Carpathian-Pannonian Region; a review of trace element and isotopic evidence from ultramafic xenoliths, Acta Vulcanologica, 7 , 219-229, 1995.

Ellouz, N. and Roca, E.: Palinspastic reconstructions of the Carpathians and adjacent areas since the Cretaceous: a quantitative approach, in: Roure, F. (Ed.): Peri-Tethyan Platforms, Editions Technip, Paris, 51-78, 1994.

Embey-Isztin, A. and Dobosi, G.: Mantle source characteristics for Miocene-Pliocene alkali basalts, Carpathian-Pannonian region: a review of trace elements and isotopic compositions, Acta Vulcanologica, 7, 155-166, 1995.

Facenna, C., Davy, P., Brun, J. P., Funicello, R., Giardini, D., Mattei, M., and Nalpas, T.: The dynamics of back-arc extension: an experimental approach to the opening of the Tyrrenian sea, Geophys. J. Int., 126, 781-795, 1996.

Fodor, L.: From transpression to transtension; Oligocene-Miocene structural evolution of the Vienna basin and the East Alpine-West Carpathian junction, Tectonophysics, 242, 151-182, 1995.

Fodor, L., Csontos, L., Bada, G., Gyorfi, I., and Benkovics, L.: Tertiary tectonic evolution of the Pannonian basin and neighbouring orogens; a new synthesis of paleostress data, Geol. Soc. London Spec. Publ., 134, 295-334, 2000.

Hippolyte, J.-C. and Sandulescu, M.: Paleostress characterisation of the "Wallachian phase" in its type area (South Eastern Carpathians, Romania), Tectonophysics, 263, 235-248, 1996.

Horvát, F.: Towards a mechanical model for the formation of the Pannonian Basin, Tectonophysics, 226, 333-357, 1993.

Horvát, F.: Phases of compression during the evolution of the Pannonian Basin and its bearing on hydrocarbon exploration, Mar. Petrol. Geol., 12, 837-844, 1995.

Horvát, F. and Cloetingh, S. A. P. L.: Stress-induced late-stage subsidence anomalies in the Pannonian basin, Tectonophysics, 266, 287-300, 1996.

Huismans, R. S., Bertotti, G., Ciulavu, D., Sanders, C. A. E., Cloetingh, S. A. P. L., and Dinu, C.: Structural Evolution of the Transylvanian Basin (Romania): a sedimentary basin in the bend zone of the Carpathians, Tectonophysics, 272, 249-268, 1997.

Huismans, R. S., Podladchikov, Y. Y. and Cloetingh, S. A. P. L.: Transition from passive to active rifting: Relative importance of asthenospheric doming and passive extension of the lithosphere, J. Geophys. Res., 106, 11 271-11 292, 2001a.

Huismans, R. S., Podladchikov, Y. Y. and Cloetingh, S. A. P. L.: Dynamic modeling of the transition from passive to active rifting, application to the Pannonian basin, Tectonics, 20, 1021-1039, $2001 \mathrm{~b}$.

Huismans, R. S. and Bertotti, G.: The Transylvanian basin, transfer zone between coeval extending and contracting regions: Inferences on the relative importance of slab pull and rift push in arc-back-arc systems, Tectonics, in press, 2002.

Huismans, R. S., Podladchikov, Y. Y., and Cloetingh, S. A. P. L.: Coeval tension and compression in the Pannonian basin: rift push force from asthenosphere doming in a convergent tectonic regime, Earth Planet. Sci. Lett., submitted, 2002.

Karig, D. E.: Origin and development of marginal basins in the western Pacific, J. Geophys. Res., 76, 2545-2561, 1971.

Keen, C. E.: 1985. The dynamics of rifting; deformation of the lithosphere by active and passive driving forces, Geophys. J. R. Astron. Soc., 80, 95-120, 1985.

Keen, C. E. and Boutilier, R. R.: Lithosphere-Asthenosphere interactions below rifts, in: Banda, E. (Ed.): Rifted Ocean-Continent boundaries, Kluwer Academic Publishers, Amsterdam, 17-30, 1995.

Lankreijer, A., Kováč, M., Cloetingh, S. A.P.L., Pitonak, P., Hloska, M., and Biermann, C.: Quantitative subsidence analysis and forward modelling of the Vienna and Danube basins; thinskinned versus thick-skinned extension, Tectonophysics, 252, 433-451, 1995.

Le Pichon, X. and Alvarez, F.: From stretching to subduction in back arc regions: dynamic considerations, Tectonophysics, 102, 343-357, 1984. 
Lenkey, L.: Geothermics of the Pannonian Basin and its bearing on the tectonics of basin evolution, Ph.D. thesis, Vrije Universiteit, Amsterdam, 214pp, 1999.

Matenco, L.: Tectonic evolution of the Outer Romanian Carpathians; constraints from kinematic analyses and flexural modelling, Ph.D. thesis, Vrije Universiteit, 160pp, Amsterdam, 1997.

Neubauer, F., Fritz, H., Genser, J., Kurz, W., Nemes, F., Wallbrech, E., Wang, X., and Willingshofer, E.: Evolution within an extruding wedge: model and application to the Alpine-Pannonian system, in: Urai, J., Lehner, F., and van der Zee, W. (Eds.): Structural Aspects of tectonic faulting (Festschrift in Honour of Georg Mandl), Springer, Berlin-Heidelberg-New York., pp141153, 2000.

Pecskay, Z., Lexa, J., Szakacs, A., Balogh, K., Seghedi, I., Konečný, V., Kováč, M., Marton, E., Kaliciak, M., Szeky-Fux, V., Poka, T., Gyarmati, P., Edelstein, O., Rosu, E., and Zec, B.: Space and time distribution of Neogene-Quaternary volcanism in the Carpatho-Pannonian region, Acta Vulcanologica, 7, 15-28, 1995.

Peresson, H. and Decker, K.: Far field effects of late Miocene subduction in the Eastern Carpathians; E-W compression and inversion of structures in the Alpine Carpathian Pannonian region, Tectonics, 16, 38-56, 1997a.

Peresson, H. and Decker, K.: The Tertiary dynamics of the northern Eastern Alps (Austria): changing paleostress in a collisional plate boundary, Tectonophysics, 272, 125-157, $1997 \mathrm{~b}$.

Ratschbacher, L., Merle, O., Davy, P., and Cobbold, P.: Lateral extrusion in the Eastern Alps; Part 1, Boundary conditions and experiments scaled for gravity, Tectonics, 10, 245-256, 1991.

Ratschbacher, L., Linzer, H. G., Moser, F., Strusievicz, R. O., Bedelean, H., Har, N., and Mogos, P. A.: Cretaceous to Miocene thrusting and wrenching along the central South Carpathians due to a corner effect during collision and orocline formation, Tectonics, 12, 855-873, 1993.

Rögl, F.: Stratigraphic correlation of the Parathetys Oligocene and Miocene, Mitteilungen Ges. Geol. Bergbaustud. Österreich, 41, 65-73, 1996.

Royden, L. H., Horvát, F., and Burchfiel, B. C.: Transform faulting, extension, and subduction in the Carpathian Pannonian region, Geol. Soc. Am. Bull., 93, 717-725, 1982.

Royden, L., Horvát, F., Nagymarosy, A., and Stegena, L.: Evolution of the Pannonian Basin system; 1, Tectonics, Tectonics, 2, 6390, 1983a.

Royden, L., Horvát, F., Nagymarosy, A., and Stegena, L.: Evolution of the Pannonian Basin system; 2, Subsidence and thermal history, Tectonics, 2, 91-137, 1983b.

Sachsenhofer, R. F., Lankreijer, A., Cloetingh, S. A.P.L., and Ebner, F.: Subsidence analysis and quantitative basin modeling in the Styrian basin (Pannonnian Basin system, Austria), Tectonophysics, 272, 175-196, 1997.
Sanders, C., Andriessen, P., and Cloetingh, S. A. P. L.: Life cycle of the East Carpathian orogen, erosion of a doubly vergent critical wedge assessed by fission track thermochronology, J. Geophys. Res., 104, 29 095-29 112, 1999.

Sanders, C.A.E.: Tectonics and erosion, competitive forces in a compressive orogen. A fision track study of the Romanian Carpathians, Ph.D. thesis, Vrije Universiteit, Amsterdam, 204pp, 1998.

Sclater, J. G., Royden, L., Horvát, F., Burchfiel, B. C., Semken, S., and Stegena, L.: The formation of the intra-Carpathian basins as determined from subsidence data, Earth Planet. Sci. Lett., 51, 139-162, 1980.

Shemenda, A. I.: Modeling of Intraplate Deformations in the Northeastern Part of the Indian Ocean, Geotectonics, 23, 223-231, 1989.

Shemenda, A. I.: Subduction of the Lithosphere and Back Arc dynamics: Insights from physical modeling, J. Geophys. Res., 98, 16 167-16 185, 1993.

Stegena, L., Geczy, B., and Horvát, F.: Late Cenozoic evolution of the Pannonian Basin, Tectonophysics, 26, 71-90, 1975.

Szabo, C., Harangi, S., and Csontos, L.: Review of Neogene and Quaternary volcanism of the Carpathian-Pannonian region, Tectonophysics, 208, 1-3, 1992.

Tari, G. and Bally, A. W.: Metamorphic core complexes at the boundary of the Eastern Alps and the Pannonian Basin, Abstracts with Programs Geological Society of America, 22, 97-98, 1990.

Tari, G., Baldi, T., and Baldi-Beke, M.: Paleogene retroarc flexural basin beneath the Neogene Pannonian Basin: a geodynamic model, Tectonophysics, 226, 433-456, 1993.

Taylor, B. and Karner, G. D.: On the evolution of marginal basins, J. Geophysics Res. 226, 1727-1741, 1983.

Toksöz, M. N. and Hsui, A. T.: Numerical stuies of back-arc convection and the formation of marginal basins, Tectonophysics, 50, 177-196, 1978.

Turcotte, D. L.: Driving mechanisms of Mountain building, in: Hsu, K. (Ed.): Controversy in Geology, 141-146, 1983.

Turcotte, D. L. and Emerman, S. H.: Mechanisms of active and passive rifting, Tectonophysics, 94, 39-50, 1983.

van Balen, R. T. and Cloetingh, S. A. P. L.: Neural network analyses of stress-induced overpressures in the Pannonian Basin, Geophys. J. Int., 121, 532-544, 1995.

van Bemmelen, R. W.: Geodynamic models for the Alpine type of orogeny (Test case II: the Alps in central Europe), Tectonophysics, 18, 33-79, 1973.

Vaselli, O., Downes, H., Thirlwall, M., Dobosi, G., Coradossi, N., Seghedi, I., Szakacs, A., and Vannucci, R.: Ultramafic xenoliths in Plio-Pleistocene Alkali basalts from the Eastern Transylvanian basin: depleted mantle enriched by vein metasomatism, J. Petrol., 1, 23-53, 1995. 